\title{
Emission of metal-oxide particles from IC-engines
}

\begin{abstract}
All conventional piston-driven combustion engines emit metal oxide particles. The main sources are the abrasion between piston-ring and cylinder, abrasion in the bearings, catalyst coating, lube-oil additives, and fuel additives for promoting the exhaust-gas after-treatment. Metal oxides, especially from transition metals, are very toxic when they are very fine. These particles have a high BET surface and penetrate the biological system. Hence, these particles must be scrutinized for quantity, size distribution and composition. This paper draws from published data and mainly the VERT certification tests, which prescribe a size specific metal analysis.

The total mass of metal oxide is $0.1-1 \mathrm{mg} / \mathrm{km}$, which appears negligible. But these particles are in the $10-20 \mathrm{~nm}$ size range. Hence, this small mass represents 1015 particles per kilometer. This is approximately the same number as soot particles emitted by diesel engines. Public health should focus on the metal oxide particles that are smaller and probalby more toxic than the soot particles. SI engines run at higher RPM and therefore emit more metal oxide particles than Diesel engines. Highly efficient filtration of such particles seems therefore necessary for all engine categories.
\end{abstract}

Keywords: metal-oxide particles, exhaust emission, IC-engines

\section{Emisja cząstek tlenków metali z silnika spalinowego}

\begin{abstract}
Wszystkie konwencjonalne tłokowe silniki spalinowe emitują cząstki tlenków metali. Głównymi źródtami tej emisji sq̨: zużycie ścierne pomiędzy układem tłok-pierścień i cylinder, zużycie ścierne zachodzace w tożyskach, powtoka reaktora katalitycznego, dodatki oleju smarującego, dodatki do paliwa wspomagające pozasilnikowa neutralizację toksyczności spalin. Tlenki metali, zwłaszcza metali przejściowych, sa bardzo toksyczne, gdy maja niewielkie wymiary. Te czastki metali maja duża powierzchnię BET i przenikają do systemu biologicznego. Dlatego musza być szczegółowo zbadane pod katem ich ilości, rozkładu wymiarowego i składu chemicznego. Niniejszy artykut zawiera dane i głównie testy certyfikacyjne VERT, opisujace analize wymiarowa wybranego metalu.

Masa całkowita tlenku metalu wynosi od 0,1 do $1 \mathrm{mg} / \mathrm{km}$, co wydaje się wartościa nieistotna. Należy jednak zaznaczyć, iż wymiar powyższych cząstek mieści się w zakresie 10 - $20 \mathrm{~nm}$. Skutkiem tego, tak niewielka masa oznacza 1015 cząstek na $1 \mathrm{~km}$, co jest w przybliżeniu taka sama wartościa, jak ilość czastek sadzy emitowanych przez silniki o zapłonie samoczynnym. Troska o zdrowie spoteczne powinna uwzględniać emisję cząstek tlenków metali, których wymiary są mniejsze i prawdopodobnie bardziej toksyczne niż cząstki sadzy. Silniki o zapłonie iskrowym osiagają większe prędkości obrotowe, dlatego emituja więcej cząstek tlenków metali niż silniki o zaptonie samoczynnym. Wysokosprawne odfiltrowanie rozważanych czastek wydaje się konieczne przy zastosowaniu w silnikach wszystkich kategorii.
\end{abstract}

Slowa kluczowe: cząstki tlenków metali, emisja spalin, silniki spalinowe

\section{Introduction}

Assuming a linear dose/effect relationship, the defining toxicity parameter is the multiplication of specific toxicity and dosage. The biological impact depends on the particles' ability to defeat the human body defense. The crucial factors are particle size and solubility. Almost insoluble particles are more hazardous than those soluble in water or fat [1, 2]. BC particles (soot) and many metal oxide particles are not soluble.

The significance of particle size can be estimated from the alveolar deposition - see Fig. 1 and the publications [3-6].

Figure 1 shows that that particles $<10 \mu \mathrm{m}$ can intrude deep into the lung. Particles smaller than $100 \mathrm{~nm}$ show a high deposition rate in the alveoli increasing with decreasing size. Tissue penetration from alveoli to the blood vessels, too, is highly dependent on particle size [4]. Therefore, the particle

\section{Wprowadzenie}

Zakładając liniowy związek między wielkością dawki a skutkiem jej oddziaływania, definiowany parametr toksyczności stanowi iloczyn określonej toksyczności i wielkości dawkowania. Wpływ biologiczny jest zależny od zdolności cząstki do pokonania warstwy ochronnej ciała człowieka. Nadrzędnymi czynnikami są tutaj rozmiar cząstki i jej rozpuszczalność. Cząstki nierozpuszczalne są bardziej niebezpieczne niż cząstki rozpuszczalne w wodzie lub w tłuszczach $[1,2]$. Cząstki sadzy i wiele cząstek tlenków metali są nierozpuszczalne.

Znaczenie rozmiaru cząstki może być oszacowane na podstawie udziału osadzonych cząstek o danej średnicy w pęcherzykach płucnych (rys. 1 i [3-6]).

Zgodnie $\mathrm{z}$ danymi przedstawionymi na rys. 1 widoczne jest, że cząstki o wymiarze $<10 \mu \mathrm{m}$ mogą docierać głęboko w obszar płuc. Cząstki o wymiarach mniejszych niż 100 nm 


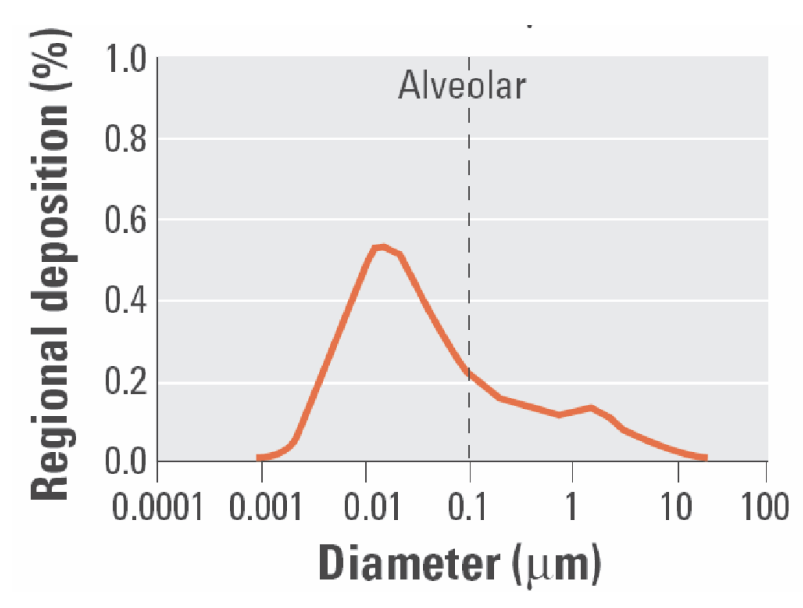

Fig. 1. Deposition of inhaled particles in the alveoli [6]. The mean particle sizes are: Diesel soot about $100 \mathrm{~nm}$; SI soot about $50 \mathrm{~nm}$ and metal oxides about $15 \mathrm{~nm}$

Rys. 1. Osadzanie pobranych czastek w plucach [6]. Średnie wymiary cząstek wynoszą: sadza w silniku ZS ok. $100 \mathrm{~nm}$, sadza w silniku ZI ok. $50 \mathrm{~nm}$, a tlenki metali ok. $15 \mathrm{~nm}$

dosage should be weighted with this size influence.

These small and insoluble metal-oxide particles penetrate the alveoli into the blood circulation. Subsequently, these are rapidly transported into the entire organism. Similar to the soot particles, the metal-oxides can cross the blood-brain barrier. These particles also cross the placenta into the fetus. The biological impact is being intensively researched and many results published [ $4-16,48-50]$.

The known toxic effects are as follows.

- Particles can cause serious local and lethal damage [7].

- The smaller particles are more cytotoxic than larger particles $[4,9]$.

- Particles can cause oxidative stress that is the precursor to inflammation [10].

- Iron, Copper, Vanadium and Zinc particles [11, 12, 48, 49, 50] and generally all transition metals, from the first row of the periodic table, are critical. This is because of their known surface activity (which is indeed used in catalysts) [13].

Moreover, these extremely fine and insoluble particles transport other toxic substances. This is described as the Trojan Horse effect [14].

Consequent to the above rapidly growing evidence, and other very intensive ongoing investigations, responsible institutions recommend restricting body intruding metal emissions to an extreme minimum [15]. Oxide particles of Iron, Copper and Zinc, which are typical for emissions from combustion engines, may be $10-100$ times more toxic than soot particles $[16,50]$.

Engineers working to curtail emissions must:

- Discover which engines emit which metal oxides in which typical size and quantity.

- Determine the engine processes that are critical sources of metal oxides.

- Develop methods and equipment to minimize the consequent health hazards. mają duży udział w obszarze płuc, tym większy, im mniejszy jest ich rozmiar.

Następuje również przenikanie składnika przez tkankę od płuc do naczyń krwionośnych, co jest w znacznej mierze zależne od rozmiaru cząstki [4]. Dlatego dawkowanie cząstek powinno być ściśle związane z rozmiarem cząstki.

Powyższe, małe i nierozpuszczalne cząstki metal-tlen przenikają do płuc i trafiają do obiegu krwi w układzie krwionośnym. W następstwie cząstki są transportowane po całym organizmie. Podobnie jak cząstki sadzy, cząstki tlenków metali mogą przechodzić przez barierę krew-mózg. Cząstki te przechodzą również przez łożysko do płodu. Wpływ biologiczny powyższych cząstek jest badany intensywnie, a uzyskane wyniki publikowane [4 - 16, 48 -50].

Wśród znanych toksycznych efektów oddziaływania cząstek można wymienić:

- powodowanie poważnych uszkodzeń miejscowych ciała lub skutki śmiertelne [7],

- cząstki o mniejszych rozmiarach są bardziej cytotoksyczne niż o większych rozmiarach [4, 9],

- mogą powodować naprężenie tlenowe, które jest zwiastunem stanu zapalnego [10],

- cząstki żelaza, miedzi, wanadu i cynku [11, 12, 48, 49, 50] i wszystkie metale przejściowe zawarte w pierwszym rzędzie układu okresowego pierwiastków są pod tym względem bardzo istotne, z powodu ich aktywności powierzchniowej (która jest wykorzystywana w reaktorach katalitycznych) [13].

Ponadto niezwykle małe i nierozpuszczalne cząstki przenoszą również inne toksyczne substancje, co jest opisane w literaturze jako tzw. ,efekt konia trojańskiego” [14].

W wyniku szybkiego uzyskiwania danych potwierdzających słuszność powyższych stwierdzeń i w wyniku innych intensywnie prowadzonych badań, instytucje odpowiedzialne za ludzkie zdrowie zalecają ograniczenie wchłanianych przez organizm ludzki emisji metali do możliwie najmniejszej wartości [15]. Cząstki tlenków żelaza, miedzi i cynku - typowe dla emisji z silników spalinowych, mogą być 10 - 100-krotnie bardziej toksyczne niż cząstki sadzy $[16,50]$.

Wysiłki inżynierów zmierzające do zmniejszenia emisji muszą koncentrować się wokół następujących zagadnień:

- rozpoznanie, jakie silniki emitują dane tlenki metali, o jakich rozmiarach i w jakiej ilości,

- wyznaczenie procesów silnikowych będących kluczowymi źródłami powstawania tlenków metali,

- rozwój metod i urządzeń do minimalizacji skutków zagrożeń zdrowia.

\section{Emisja cząstek tlenków metali od zużycia ciernego}

Materiał ulega zużyciu ściernemu pomiędzy pierścieniem tłoka a tuleją cylindrową, od wałka rozrządu i zaworów i w łożyskach. Powyższe zjawiska występują we wszystkich silnikach tłokowych i nie można im zapobiec, również w przyszłych konstrukcjach silników. Metale, takie jak Fe, $\mathrm{Cr}$, Ni i Co ulegają zużyciu ściernemu w wyniku tarcia 


\section{Metal oxide particle emissions due to abrasion}

Material is abraded between piston ring and cylinder liner, from camshafts and valves, and in the bearings. These phenomena, occurr in all piston engines, and cannot be prevented, also not in the future designs. The metals $\mathrm{Fe}, \mathrm{Cr}$, $\mathrm{Ni}, \mathrm{Co}$ are abraded due to friction between the piston-ring and cylinder-liner. $\mathrm{Cu}$ and $\mathrm{Pb}$ are abraded from the bearings. The piston/cylinder friction indeed releases the most material [17 - 21]. The publications [17] and [18] describe the processes in detail. The abrasion is not much dependent on the piston velocity. The bigger factor is the number of stroke reversals, i.e. RPM dependent. This explains why SI engines, which usually run at higher RPM, abrade almost twice as much metal than Diesel engines. This also explains the durability of Diesel engines.

The mass of abraded metal is about 0.1 till $1 \mathrm{mg} / \mathrm{km}$ $[19,20]$. It is mostly Iron and some Aluminum and Copper. Excessive abrasion occurs during lubrication deficit, i.e. at cold start. Above average abrasion is prevalent during short trips, e.g. urban stop-and-go driving.

Comprehensive data is available for different engine types [26]. Those HDV tests compared Diesel engines (with and without particle filter) against CNG fueled SI engines. The Diesel engines, without particle filter, emitted about 0.5 $\mathrm{mg} / \mathrm{km}$ of abraded metals such as Fe and $\mathrm{Cu}$. Several CNG SI engines emitted twice as much.

A CARB investigation [24] reports total metal-oxide emissions of 0.5 till $1.5 \mathrm{mg} / \mathrm{km}$ from HDV in various driving cycles.

\section{Metal oxide particle emissions from lube oil and fuel additives}

Most industrialized nations, after intensive efforts, legislated limits for the $\mathrm{Pb}$ and $\mathrm{Mn}$ content of fuels for road traffic. However, many countries do not curb fuel additives for offroad engines. Also uncontrolled are light and medium heating oils, and heavy oils fueling ships, etc. Inexplicably, nowhere is the metal content of vehicular lube oils controlled.

Metallic additives have an important function in lube oils. Those additives diminish wear and constrain sulfur- induced acidification. Mostly $\mathrm{Zn}$ and $\mathrm{Ca}$ compounds are used. The metal content of fresh lube oils on the market is found to be :
Zinc
$0.1-0.2 \%$
Calcium
$0.5 \%$
Boron
$0.09 \%$
Magnesium
$0.002-0.004 \%$

After prolonged deployment, the lube oil also contains abraded Iron, Copper, Lead, Magnesium, Aluminum and Nickel.

Assume an extreme, but not unrealistic, oil-consumption of $1 \%$ of the fuel-consumption: Then the estimated $\mathrm{Zn}$ emission is about $1 \mathrm{mg} / \mathrm{km}$. Moreover, $\mathrm{Ca}$ is emitted and all the abraded metals. Good new engines emit a tenth of that value.

Investigations comparing Diesel and CNG engines [26] report $\mathrm{Zn}$ emissions of $0.2 \mathrm{mg} / \mathrm{km}$ from Diesel and 0.4 $\mathrm{mg} / \mathrm{km}$ from $\mathrm{CNG}$. między pierścieniem tłokowym a tuleja cylindrową. $\mathrm{Cu}$ i $\mathrm{Pb}$ pochodzą od łożysk. Tarcie w układzie tłok-cylinder rzeczywiście sprawia, iż następuje zużycie większości materiału [17 - 21]. Powyższe procesy opisano szczegółowo w publikacjach [17] i [18]. Istotniejszym czynnikiem jest liczba suwów silnika, zależnych od prędkości obrotowej. Tłumaczy to, dlaczego silniki o zapłonie iskrowym, które zazwyczaj pracują przy większych prędkościach obrotowych, mają prawie dwukrotnie większe zużycie ścierne metali niż silniki o zapłonie samoczynnym. Wyjaśnia to również trwałość silników o ZS.

Masa zużytego ściernie metalu wynosi od 0,1 do 1 $\mathrm{mg} / \mathrm{km}[19,20]$. Głównie dotyczy to żelaza, aluminium oraz miedzi. Nadmiernie zużycie ścierne pojawia się podczas niedoboru oleju smarującego, tzn. podczas zimnego startu silnika. Powyższe nadmierne zużycie ścierne przeważa podczas krótkich podróży, np. jazdy w ruchu miejskim z częstymi zatrzymaniami i uruchomieniami silnika.

Wyczerpujące dane dotyczące zużycia ściernego materiału i emisji tak powstałych cząstek metali są dostępne dla różnych rodzajów silników, np. w [26]. Testy dla pojazdów typu HDV porównują silniki o zapłonie samoczynnym (mające filtr cząstek stałych i bez filtra) z silnikami o zapłonie iskrowym zasilanymi CNG. Silniki o zapłonie samoczynnym bez filtra cząstek stałych emitowały 0,5 mg/km zużytego ściernie metalu, takiego jak Fe i Cu. Dla wybranych silników o zapłonie iskrowym zasilanych CNG emisja ta była dwukrotnie wyższa.

Badania CARB [24] wskazują, iż emisja całkowita tlenków metali dla pojazdów HDV w różnych cyklach jezdnych wynosi od 0,5 do $1,5 \mathrm{mg} / \mathrm{km}$.

\section{Emisja cząstek tlenków metali od oleju smarującego i dodatków paliwowych}

Większość państw uprzemysłowionych, wskutek wielu wysiłków, objęło normą wartości graniczne dla zawartości $\mathrm{Pb}$ i Mn w paliwie dla drogowego ruchu ulicznego. Jednakże wiele państw nie ogranicza ilości dodatków do paliwa dla silników o zastosowaniach pozadrogowych. Podobnie nie są kontrolowane statki na lekko i średnio podgrzewany olej, olej ciężki itd. i nigdzie nie stosuje się kontroli zawartości metali w olejach smarujących pojazdów.

Dodatki metali mają zasadnicze znaczenie w olejach smarujących: zmniejszają ich zużycie i hamują zakwaszanie od siarki. Głównie stosuje się dodatki Zn i Ca. Skład metalu w nowym oleju smarującym wynosi:

cynk $\quad 0,1-0,2 \%$

wapń $\quad 0,5 \%$

bor $\quad 0,09 \%$

magnez $0,002-0,004 \%$

Po wydłużonym okresie użytkowania olej smarujący zawiera ponadto żelazo, miedź, grafit, magnez, aluminium i nikiel (powstałe w wyniku zużycia ściernego).

Zakładając ekstremalne, lecz możliwe zużycie oleju stanowiące 1\% zużycia paliwa, oszacowana emisja Zn może wynieść $1 \mathrm{mg} / \mathrm{km}$. Ponadto występuje emisja Ca i wszystkich metali z procesu zużycia ściernego. Nowoczesne silniki mają emisję 10\% powyższej wartości. 
One DI Diesel engine study [27] meticulously tracked the metal content of lubrication oil. The results show that most of the metal oxides remain in the engine, e.g. $69 \%$ of the $\mathrm{Zn}$. The $\mathrm{Zn}$ emission, depending on the operating point, was up to about $0.1 \mathrm{mg} / \mathrm{km}$. The Ca emissions were fourfold.

Substantial higher emissions come from small two-stroke engines. These are deployed in mopeds, motorbikes and equipment such as chain saws. These engines are lubricated by adding $>2 \%$ of lube oil to the fuel. The specific fuel consumption is higher, too. Thus, the specific metal emissions are four times those from above discussed larger 4-stroke-engines. Metal-free lube oils were investigated [37] for mixing with two-stroke fuel. The manufacturers predict comparable performance for the non-metallic lubes. Without compulsion, such lube oils are only deployed in special situations [40].

Many emerging and developing countries unfortunately tolerate metallic fuel additives. The resulting emissions of ash particles were recently investigated [31] on a gasoline passenger car. The fuel additives were $\mathrm{Mn}, \mathrm{Fe}$ and $\mathrm{Pb}$ in concentrations up to $18 \mathrm{ppm}$. Very high metal-oxide emissions of $2 \times 10^{8} / \mathrm{cc}$ were measured for ultrafine particles of about $10 \mathrm{~nm}$.

This measurement is consistent with those resulting from $\mathrm{FBC}$, which is often added to promote regeneration in DPF. Results are reported for DPF fitted ex-factory [42] and retrofitted $[43,44]$. The measurements show a bimodal size distribution with a marked peak at very small size when the fuel additive exceeds $20 \mathrm{mg}$ metal per $\mathrm{kg}$ fuel. The peak disappears for lower additive concentrations. Clearly, the metal oxide particles are deposited on larger soot particles (Fig. 2).

\section{Metal oxide particle emissions from coatings in catalytic converters and particle filters}

To achieve high catalytic effectiveness, the catalyst must be very finely distributed on the substrate. This enables a

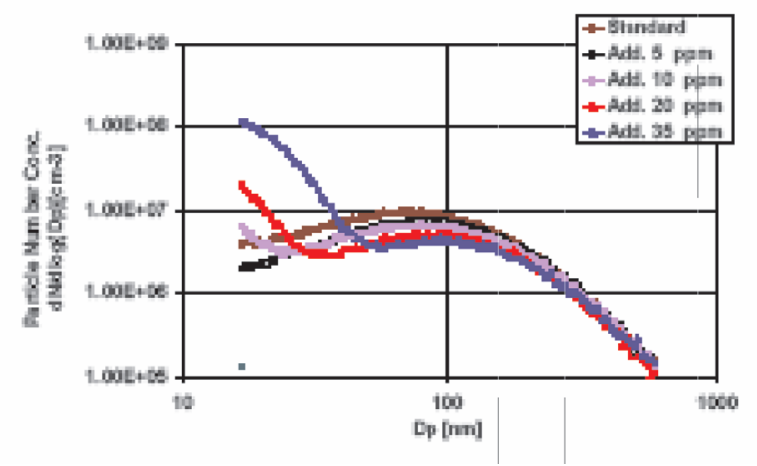

Fig. 2. Particle size distribution when $\mathrm{FBC}(\mathrm{Fe})$ is dosed in different concentrations [45]. At high concentrations, there is a significant peak of free metal oxide emissions sized about $20 \mathrm{~nm}$. At lower (nowadays realistic) concentrations, the metal oxide particles are "stealth" riding on the soot particle

Rys. 2. Rozkład wymiaru cząstki przy różnym dozowaniu $\mathrm{FBC}(\mathrm{Fe})$ [45]. Dla dużych stężeń występuje duża wartość maksymalna emisji swo-

bodnych tlenków metali o wymiarze ok. $20 \mathrm{~nm}$. Dla mniejszych stężeń czastki tlenków metali osadzaja się na czastce sadzy
Badania porównawcze silników o zapłonie samoczynnym i silników zasilanych CNG [26] wskazują, że emisja Zn wynosi 0,2 mg/km dla silników o ZS oraz $0,4 \mathrm{mg} / \mathrm{km}$ dla silników zasilanych CNG.

Badania silników o ZS typu DI opisane w [27] umożliwiły szczegółowe wyznaczenie składu metali w oleju smarującym. Wyniki badań wskazują, iż większość tlenków metali pozostaje w silniku, np. 69\% Zn. Emisja Zn, zależnie od punktu pracy silnika, wyniosła do $0,1 \mathrm{mg} / \mathrm{km}$. Emisja Ca była 4-krotnie większa.

Większa emisja pochodzi od niewielkich silników 2-suwowych. Dotyczy to mopedów, motorowerów i urządzeń takich, jak piły łańcuchowe. Silniki powyższe są smarowane $\mathrm{w}$ wyniku dodania $>2 \%$ oleju smarującego do paliwa. Jednostkowe zużycie paliwa jest również większe. W ten sposób emisja danego metalu jest 4-krotnie większa niż dla powyżej rozważanych większych silników 4-suwowych. Badano oleje smarujące bez dodatków metali [37], mieszane z paliwem stosowanym w silnikach dwusuwowych. Producenci przewidują osiągi dla olejów bez dodatków metali porównywalne do uzyskanych przy olejach zawierajacych dodatki.

Oleje smarujące niemające dodatków są używane jedynie w specjalnych sytuacjach, których warunki opisano $\mathrm{w}[40]$.

Wiele dopiero rozwijających się państw, niestety, toleruje stosowanie dodatków metali w paliwie. W ostatnim czasie badano emisję cząstek popiołów [31] w silnikach o zapłonie iskrowym samochodów osobowych. Dodatkami do paliwa były $\mathrm{Mn}, \mathrm{Fe}$ i $\mathrm{Pb}$ o stężeniu do 18 ppm. Bardzo dużą emisję tlenków metali $2 \times 10^{8} \mathrm{~cm}^{-3}$ odnotowano dla cząstek o niewielkich rozmiarach osiągających $10 \mathrm{~nm}$. Pomiar ten jest zgodny z wynikami uzyskanymi dla FBC, który jest często dodawany celem wspomagania procesu regeneracji w filtrach cząstek stałych. Wyniki dotyczą filtrów cząstek stałych fabrycznych i zmodyfikowanych konstrukcyjnie $[43,44]$. Pomiary ukazują bimodalny rozkład wymiarowy z zaznaczoną wartością maksymalną emisji dla bardzo małego rozmiaru cząstki, gdy dodatek paliwa przekracza wartość $20 \mathrm{mg} / \mathrm{kg}$ paliwa. Dla mniejszych stężeń dodatku powyższa wartość nie występuje. Źródła tego należy upatrywać w tym, iż cząstki tlenków metali są osadzone na większych cząstkach sadzy (rys. 2).

\section{Emisja cząstek tlenków metali z warstw reaktorów katalitycznych i filtrów cząstek stalych}

W celu osiągnięcia wysokiej sprawności katalitycznej, katalizator musi być bardzo drobno rozprowadzony na podłożu. Działanie takie umożliwia uzyskanie znacznej liczby aktywnych ośrodków i opóźnienie starzenia reaktora. Jeżeli wiązanie krystaliczne słabnie, wówczas są emitowane bardzo niewielkie cząstki. Badanie tego zjawiska przeprowadzone w 1977 r. na granulowanym reaktorze katalitycznym [29] ujawniło niezwykłe wyniki: około $0,02 \mathrm{mg}$ Pt na $1 \mathrm{~km}$, tzn. około 2 - 5 g metalu szlachetnego utracono w okresie eksploatacji samochodu osobowego. Ekolodzy przerazili się i zaczęli analizować zawartość Pt w roślinności w pasie 
large number of active centers, and retards aging. If the crystalline binding weakens, then ultrafine particles are emitted. An early 1977 investigation of this phenomenon, in a pellet catalytic converter [29] revealed a shocking result: about $0.02 \mathrm{mg}$ Pt was emitted per $\mathrm{km}$, i.e. about $2-5 \mathrm{~g}$ of precious metal lost during the life of a passenger car. The environmentalists were appalled and began analyzing the $\mathrm{Pt}$ content in roadside vegetation - up to $20 \mu \mathrm{g}$ Pt was detected per kg soil. Detailed investigation of a typical modern 3-way catalytic converter [30] on ceramic monolithic substrate, however showed an average Pt emission of "only" 100 $\mathrm{ng} / \mathrm{km}$. This is less than $1 \%$ of the 1977 measurements but nevertheless not negligible. Higher emissions can occur for other metals, depending on the coating technology. For example, Vanadium is deployed very close to its thermal mobility threshold. Such emissions must be restricted.

\section{Number and size distribution of metal oxide particles in exhaust}

The general assumption is that mechanical destruction of materials results in a particle size $>1 \mu \mathrm{m}$. Most of the particles observed in the exhaust-gas are much smaller. The mean measured distribution is in the range $10-20 \mathrm{~nm}$. This can only occur through nucleation from the gas phase [22]. That study reported the mean value of $19.3 \mathrm{~nm}$ from the lognormal distribution of iron-oxide particles originating from the vapor phase. Hence the conclusion, which Israël already published [21], that the metal particles partially vaporized and nucleated from this vapor phase.

There are 2 hypotheses for this phenomenon. Firstly, the so-called thermal explosion that Grigull [23] described. The heat released during abrasion is postulated to locally melt the metal. However, this hypothesis does not fully explain the vaporization. The second hypothesis is combustion. Abraded particles could be blown back into lube oil and transported into the combustion zone. The abraded particles then vaporize, during combustion of the oil droplets, and subsequently renucleate. More easily explained is the formation of such small particles from the additives to lube oil and fuel. These additives are metal organic compounds and access the combustion zone.

Several studies $[24,25,31]$ report that these metal emissions in the exhaust-gas mainly occur in the size range 10 $-20 \mathrm{~nm}$. Also published [24] are particle counts of $10^{6} / \mathrm{cc}(\mathrm{Zn}$, $\mathrm{Ca})$ and $10^{5} / \mathrm{cc}(\mathrm{Fe})$. When metallic additives are used [31], the particle count increased to $10^{8} / \mathrm{cc}$. Assuming density of 4 $\mathrm{g} / \mathrm{cc}$, the mass of a $20 \mathrm{~nm}$ metal oxide particle is $4 \times 10^{-17}$ g. For a $10^{6} / \mathrm{cc}$ emitting Diesel engine, at medium load, this corresponds to about $5 \times 10^{12} / \mathrm{km}$, which is a total metal emission mass of about $0.2 \mathrm{mg} / \mathrm{km}$.

The combustion generated metal oxide particles can deposit on soot particles. If there are only few soot particles, then the metal-oxide particles appear as unattached aerosol components in the exhaust-gas. Attached metal oxide particles are not detectable in the size distribution. Unattached metal-oxide particles manifest as a distinct bimodal distribution. The metal-oxide particles peak at about $10-20 \mathrm{~nm}$, as przydrożnym - wykryto aż do $20 \mu \mathrm{g}$ Pt na $1 \mathrm{~kg}$ masy gruntu. Jednakże szczegółowe badania typowego nowoczesnego trójfunkcyjnego reaktora katalitycznego [30] na monolitycznym podłożu ceramicznym pokazały, iż średnia emisja Pt wyniosła jedynie $100 \mathrm{ng} / \mathrm{km}$. Wartość ta jest mniejsza niż 1\% wartości z badań w $1977 \mathrm{r}$., lecz mimo to jest wartością istotną. Większa emisja może być udziałem innych metali, zależnie od technologii wykonania podłoża reaktora. Dla przykładu, wanad jest rozlokowany bardzo blisko swojej granicy zmienności cieplnej. Taka emisja musi być ograniczona.

\section{Rozkład liczbowy i wymiarowy cząstek tlenków metali w spalinach}

Zakłada się, iż uszkodzenie mechaniczne materiału powoduje powstanie w spalinach cząstek tlenków o rozmiarach $>1 \mu \mathrm{m}$. Większość cząstek obserwowanych w spalinach ma znacznie mniejsze rozmiary.

Średni zmierzony rozkład cząstek wynosi $10-20 \mathrm{~nm}$. Może to pojawić się jedynie w wyniku zarodkowania od fazy gazowej [22]. W przeprowadzonych badaniach określono, że średnia wartość rozmiaru dla logarytmiczno-normalnego rozkładu cząstek żelazowo-tlenkowych powstałych z fazy gazowej wyniosła 19,3 nm. Można dzięki temu dojść do wniosku [21], że cząstki metali uległy częściowo odparowaniu i procesowi zarodkowania od podanej fazy gazowej.

Istnieją dwie hipotezy powyższego zjawiska. Pierwszą z nich, nazwaną ,wybuchem cieplnym”, opisał Grigull w pracy [23]. Ciepło wydzielone podczas procesu zużycia ściernego lokalnie stapia metal. Jednakże powyższa hipoteza nie wyjaśnia całkowicie parowania. Druga z hipotez dotyczy spalania. Cząstki powstałe przez zużycie ścierne mogły być z powrotem wdmuchiwane do oleju smarującego i przenoszone w obszar spalania. Wówczas cząstki te ulegają odparowaniu podczas spalania kropel oleju smarującego, a następnie ponownemu zarodkowaniu.

Prostszym wyjaśnieniem występowania powyższego zjawiska jest formowanie małych cząstek $\mathrm{z}$ dodatków stosowanych w oleju smarującym i paliwie. Dodatki te są organicznymi związkami metali i docierają do obszaru spalania.

Przeprowadzone analizy zawarte w pracach $[24,25,31]$ wskazują, że rozważana emisja metali w spalinach głównie występuje dla zakresu wymiarowego $10-20 \mathrm{~nm}$. Uzyskana $\mathrm{z}$ badań i przedstawiona $\mathrm{w}$ [24] liczba cząstek wyniosła $10^{6}$ $\mathrm{cm}^{-3}$ dla $\mathrm{Zn}$ i Ca oraz $10^{5} \mathrm{~cm}^{-3}$ dla Fe. Gdy zastosowano dodatki metali [31], liczba cząstek wzrosła do $10^{8} \mathrm{~cm}^{-3}$. Przy założeniu, że wartość gęstości wynosi $4 \mathrm{~g} / \mathrm{cm}^{3}$, masa cząstek tlenków metali o rozmiarze $20 \mathrm{~nm}$ wynosi $4 \times 10^{-17} \mathrm{~g}$. Dla silnika o ZS pracującego w zakresie średnich obciążeń, liczba cząstek wyniosła $10^{6} \mathrm{~cm}^{-3}$, co odpowiada liczbie $5 \times 10^{12} \mathrm{~km}^{-1}$, czyli całkowitej emisji metali ok. $0,2 \mathrm{mg} / \mathrm{km}$.

Cząstki tlenków metali generowane w procesie spalania mogą osiadać na cząstkach sadzy. Jeżeli jest jedynie kilka cząstek sadzy, wówczas cząstki tlenków metali pojawiają się jako niepołączone składniki aerozolu w spalinach. Osadzone cząstki tlenków metali nie są wykrywane w analizie rozkładu 
shown in Fig. 2 for fuel additives. But not all metal-oxide particles are in this peak of unattached aerosol components. Some of the metal-oxide particles are in other size classes and deposited on soot particles. A quantitative analysis thus requires investigating the composition of all size classes.

Respiratory air at heavy traffic locations [29] contains, in the particle fraction under $180 \mathrm{~nm}$ (PM0.18), mainly the following metal constituents due to engine emissions:

$\begin{array}{ll}\mathrm{Ca} & 2.77 \% \\ \mathrm{Al} & 1.24 \% \\ \mathrm{Fe} & 0.92 \% \\ \mathrm{Cu} & 0.12 \%\end{array}$

The ultrafine particles are about 5\%. It confirms the determined $3 \%$ number measured on HDV [24].

The publications cited here report remarkably consistent results. Diesel engines emit metal-oxide particles of $0.1 \mathrm{mg} /$ $\mathrm{km}$ (LDV) till $1 \mathrm{mg} / \mathrm{km}$ (HDV). SI engines emit the double. These particles are emitted in the mobility size of $10-20$ $\mathrm{nm}$, i.e. in the deposition-maximum of the alveoli. The metaloxide particles are mostly insoluble and therefore persistent. Moreover, these transition metals are surface active. Thus, these fulfil all criteria of a very toxic air pollutant. Are these metal oxide particles the actual toxic substance of engine emitted particles? This aspect must be precisely investigated to develop appropriate technology and optimize the emission after-treatment.

The above comments are derived from a literature survey. The specified methods in the VERT test procedure are described below. Some additional results are presented, too.

\section{Size-spezific metal analysis for particle fitler systems in the VERT test procedure}

The testing of particle filters is according to their suitability for filtering alveoli intruding solid particles. The VERT tests were developed 1993-1998 based on the principles of occupational health. From 1998 onwards, the tests are routinely used for testing and approval of particle filters in Switzerland. The VERT tests are also used for workplace certification in Germany and Austria. The VERT tests are codified in the Swiss standard SNR 277205 [34]. The VERT instrumentation and procedures are the forerunner of the PMP procedure. PMP is the basis for new European emission legislation [46]. VERT also tests many other criteria [32]. Those include secondary emissions [33] and the size specific emissions of metal oxide particles $[35,36]$.

The ISO $8178 / 4 \mathrm{C} 1$ driving cycle is used to analyze secondary emissions and metal oxide emissions (Fig. 3).

The cycle is driven twice as legally prescribed in the specified sequence. The total operating time is 200 minutes. This long time is necessary to collect sufficient material for the trace analysis. There is no pause between the individual operating points. Instead, the transition is regarded as realistic transient element in the analysis. The temperatures are in a band, which facilitates the formation of secondary emissions, and also the de-novo synthesis of dioxins. At high loads, regeneration of the particle filter occurs. Thus, the pertinent phenomena are captured, too. wymiarowego. Niepołączone cząstki tlenków metali uzewnętrzniają wyraźny rozkład bimodalny. Impulsowy wzrost wartości maksymalnej cząstek tlenków metali jako dodatków do paliwa odnotowano dla wymiaru $10-20 \mathrm{~nm}$, co pokazano na rys. 2 . Nie wszystkie jednak cząstki tlenków metali są zawarte $\mathrm{w}$ powyższym wzroście wartości maksymalnej nieosadzonych związków aerozolu. Niektóre z cząstek tlenków metali mają inne klasy wymiarowe i są osadzone na cząstkach sadzy. Analiza ilościowa wymaga więc badania składu cząstek wszystkich klas wymiarowych.

Powietrze $\mathrm{z}$ otoczenia dla trudnych warunków ruchu [29] zawiera, dla frakcji cząstki poniżej $180 \mathrm{~nm}$ (PM 0,18), głównie następujące cząstki metali w emisji silnikowej:

$\begin{array}{ll}\mathrm{Ca} & 2,77 \% \\ \mathrm{Al} & 1,24 \% \\ \mathrm{Fe} & 0,92 \% \\ \mathrm{Cu} & 0,12 \%\end{array}$

Cząstki o bardzo małych wymiarach stanowią 5\% udziału emisji. Potwierdza to wyznaczoną wartość 3\% uzyskaną w pomiarach pojazdów typu HDV [24].

Cytowane powyżej źródła literaturowe wskazują na bardzo zgodne uzyskiwane wyniki badań. Silniki o ZS emitują cząstki tlenków metali na poziomie $0,1 \mathrm{mg} / \mathrm{km}$ dla pojazdów LDV, do $1 \mathrm{mg} / \mathrm{km}$ dla pojazdów HDV. Silniki o ZI emitują dwa razy większą ilość tych cząstek. Rozkład wymiarowy emisji cząstek tlenków metali wynosi 10 - 20 nm, co odpowiada maksymalnemu osadzaniu cząstek w płucach.

Cząstki tlenków metali są przede wszystkim nierozpuszczalne i trwałe. Ponadto rozważane metale przejściowe są aktywne powierzchniowo. W konsekwencji spełniają wszystkie kryteria bardzo toksycznych związków zanieczyszczających powietrze. Czy wspomniane cząstki tlenków metali są istotnie toksycznymi substancjami cząstek emitowanych przez silnik? Aspekt ten musi być szczegółowo zbadany w celu rozwoju odpowiedniej technologii i optymalizacji pozasilnikowych metod obniżenia emisji.

Powyższe rozważania pochodzą z badań opisanych $\mathrm{w}$ literaturze. Określone metody w procedurze badawczej VERT opisano poniżej. Zaprezentowano ponadto wybrane dodatkowe wyniki badań.

\section{Analiza wymiarowa wybranych metali dla systemów filtrów cząstek stałych w procedurach testu VERT}

Badanie filtrów cząstek stałych jest dokonywane zgodnie $\mathrm{z}$ ich przydatnością dla procesu filtrowania stałych cząstek zdolnych do przenikania do pęcherzyków płucnych. Testy badawcze VERT rozwijano w latach 1993-1998, opierając się na zasadach zdrowia zawodowego. Od roku 1998 powyższe testy stosuje się zwyczajowo do badania filtrów cząstek stałych na terenie Szwajcarii. Testy VERT są również stosowane w Niemczech i Austrii do certyfikacji miejsca pracy. Testy VERT są skodyfikowane w szwajcarskiej normie SNR 277205 [34]. Oprzyrządowanie i procedury testów VERT są prekursorem procedury PMP. Powyższy program pomiaru cząstek stałych jest podstawą nowych europejskich norm emisji [46]. VEST uwzględnia również inne kryteria [32]: 


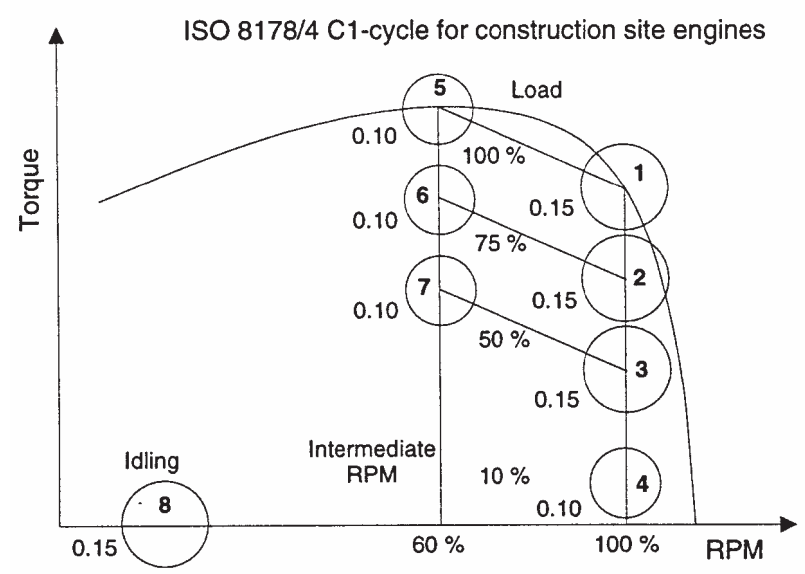

Fig. 3. ISO 8178/4 C1 driving cycle. Used to VERT test particle filter systems for secondary emissions and metal oxide emissions

Rys. 3. Cykl jezdny ISO 8178/4 C1 zastosowany w badaniach systemów filtrów cząstek stałych wg testu VERT dla emisji wtórnej i tlenków metali

The samples, during the entire test time, are extracted flow-proportional, as illustrated in Fig. 5. Undiluted sampling to determine the trace elements. CVS dilution as usual for the standard gas and VOC analysis. Partial flow dilution, using an AVL Smart-Sampler for the granulometry and the size-specific metal analysis.

For the metal analysis, the exhaust-gas is diluted about 1:10. Then the ELPI impactor partitions it into 13 size classes in the range of $<30 \mathrm{~nm}$ till $10 \mu \mathrm{m}$. The analysis of the impactor films is done according to the ICPMS procedure described below.

\section{Metal analysis methodology}

The ultra-trace determination of metals requires a strict optimization of the entire sampling procedure, sample preparation and analysis. Sampling mistakes can yield misleading results [36].

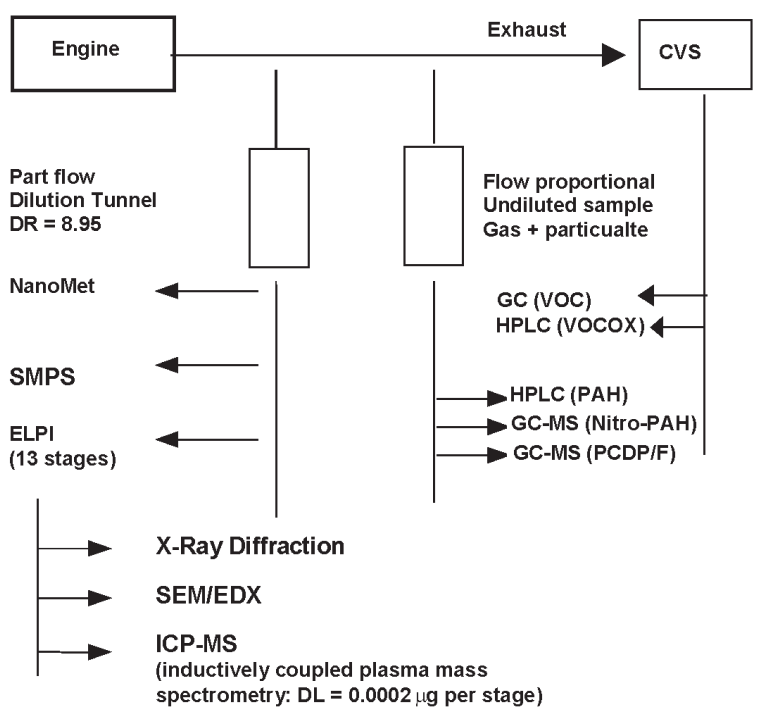

Fig. 5. Sampling schematic

Rys. 5. Schemat układu poboru spalin

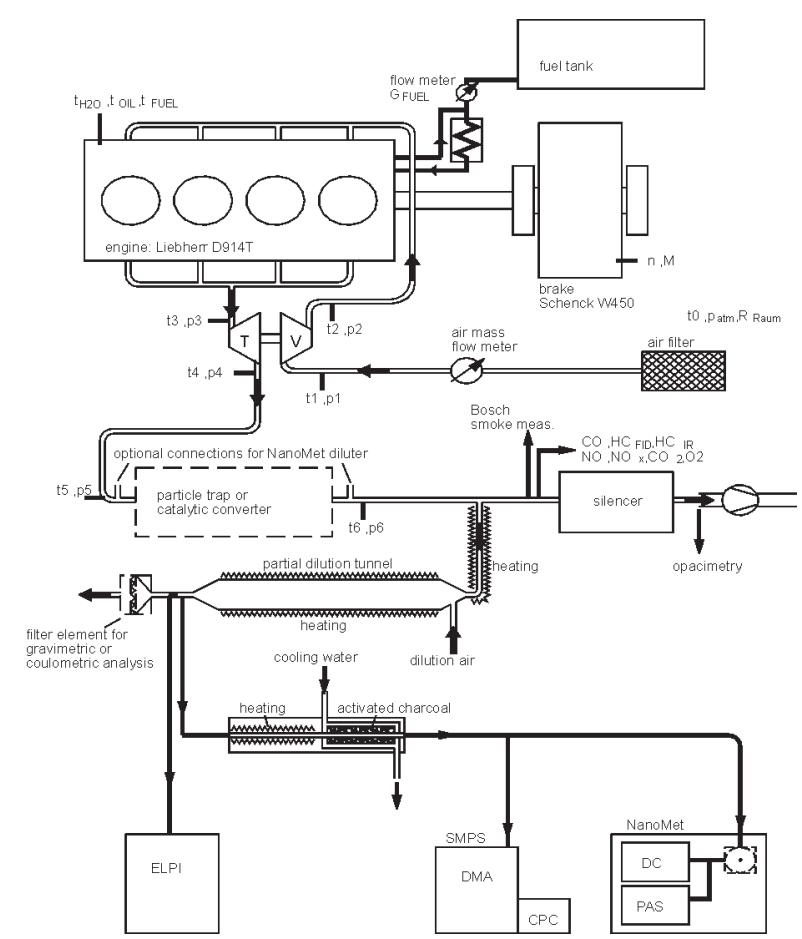

Fig. 4. Is a schematic of the test rig. It shows the arrangement for the gas measurement and the granulometry. Also shown is particle sampling to the Electrical Low Pressure Impactor ELPI for the size specific analysis Rys. 4. Schemat stanowiska badawczego; przedstawiono rozmieszczenie układów do pomiaru gazowych składników i analizy wymiarowej oraz próbkowanie cząstek do systemu ELPI dla wybranej analizy wymiarowej

emisję wtórną [33] i określone emisje z udziałem analizy wymiarowej cząstek tlenków metali $[35,36]$.

Cykl badawczy ISO 8178/4 C1 jest stosowany do analizy emisji wtórnej i tlenków metali (rys. 3). Cykl jest przeprowadzany dwukrotnie w określonej kolejności, zgodnie z wymaganiem prawnym. Całkowity czas pracy wynosi 200 minut. Tak długi okres jest niezbędny do zebrania odpowiedniego materiału badawczego do analizy śladowej. Nie ma przerwy między odpowiednimi punktami pracy, natomiast wymagana jest zmiana warunków pracy, jako rzeczywisty niestacjonarny element $\mathrm{w}$ analizie. Temperatury mieszczą się w przedziale, który umożliwia tworzenie emisji wtórnej i syntezy de-novo dioksyn. Dla większych obciążeń występuje regeneracja filtra cząstek stałych.

$\mathrm{Na}$ rysunku 4 przedstawiono schemat stanowiska badawczego zastosowanego do oceny wymiarowej wybranych metali dla systemów filtrów cząstek stałych w procedurach testu VERT.

Próbki badawcze, podczas całego okresu trwania testu, są pobierane proporcjonalnie do przepływu, co zilustrowano na rys. 5. Próbkowanie bez rozcieńczenia umożliwia określenie składników śladowych. Zastosowano system rozcieńczania CVS używany do oceny standardowego gazu i analizę VOC. Dodatkowo występuje rozcieńczanie częściowo przepływowe, z zastosowaniem układu pomiarowego AVL Smart-Sampler do oceny granulometrycznej i analizy wymiarowej metali.

Do analizy metali rozcieńcza się spaliny w proporcji 1:10. Następnie impaktor ELPI dzieli cząstki na 13 klas 


\section{Sample preparation and analysis}

All samples are digested with acid mixtures in a microwave oven. The vessels used for the digestion should be carefully cleaned before use to achieve best detection limits.

All cleaning digestions must be verified using ICPMS (inductively coupled plasma mass spectrometry) to ensure that the contamination level is low enough. Only ultra-clean vessels should be used.

Depending on the filter material and the analyte, sampling filters are digested by the following acid mixtures in a microwave oven:

- Nitric acid $\mathrm{HNO}_{3}$

- A mixture of nitric acid $\mathrm{HNO}_{3}$ and hydrogen peroxide $\mathrm{H}_{2} \mathrm{O}_{2}$

- A mixture of nitric acid, hydrochloric acid $\mathrm{HCl}$ and hydrogen peroxide $\mathrm{H}_{2} \mathrm{O}_{2}$

The resulting solutions are analyzed with ICPMS. Depending on the analyte, a quadruple ICPMS (ELAN 6000, Perkin Elmer/Sciex) or a high resolution ICPMS (ELEMENT 2, Thermofinnigan) is used.

Reliable results can only be achieved if the detection limit of the entire procedure, including sampling, sample preparation and analysis are determined. Therefore, blanks of fresh filter material and field-blanks (processed as similarly as possible to sampling filters in the field) should be sampled, digested and determined.

Contamination risk and memory effects are not negligible especially for ubiquitous metals. Usually the metal determination is more limited by the sampling procedure and sampling preparation than by detection limits of the analytical method [36]. Test engines, fuel and lubrication oil are shown in Table 1-3.

\section{Results of the size specific metal-analysis AC Cording to VERT}

Shown first are the SMPS particle size distribution for two representative cases with and without particle filter. The PMP procedure was used to sample before size classification and particle counting. The PMP comprises heating the exhaust-gas to $300^{\circ} \mathrm{C}$, then 1:100 dilution, so that all volatile particles (droplets) are vaporized and only solid particles measured. The test is done at 8 operating points and hence 8 SMPS spectra are shown for each test case. At least 3 scans are done for each spectrum. Point 8 represents low idling.

Figure $6 \mathrm{a}$ and $6 \mathrm{~b}$ are results from a catalytically coated particle filter system. Its ceramic wall-flow filter substrate is Fe coated to accelerate regeneration from deposited soot. Hence, the Fe emissions were analyzed.

Remarkably (Fig. 6a), at 7 of the 8 operating points, the particle size distribution is uniform, independent of RPM and load. Only the idling point has a different distribution. Meanwhile, more than 20 particle filter systems were tested for secondary emissions. All show the same pattern: at the idling point, there is excess air and thus relatively low concentration of the soot particles in the exhaust-gas volume. The typical soot peak at $100 \mathrm{~nm}$ is almost imperceptible at this scale. wymiarowych w zakresie od $<30 \mathrm{~nm}$ do $10 \mu \mathrm{m}$. Analiza powłok impaktora jest realizowana zgodnie z procedurą ICPMS, którą opisano poniżej.

\section{Metodologia analizy metali}

Określenie ultramałych śladów metali wymaga ścisłej optymalizacji całej procedury poboru próbki do analizy, przygotowania próbki i jej analizy. Błędy próbkowania mogą skutkować uzyskaniem niewłaściwych wyników [36].

\section{Przykladowe przygotowanie i analiza}

Wszystkie próbki są roztwarzane mieszankami kwasowymi w piecu mikrofalowym. Naczynia do ekstrahowania powinny być przed użyciem dokładnie oczyszczone, celem uzyskania najlepszych wartości granicznych wykrycia sladów metali. Wszystkie czyste roztwarzania muszą być zweryfikowane z zastosowaniem ICPMS (spektroskopii masowej z zastosowaniem sprzężonej plazmy), aby zapewnić niewielki poziom zanieczyszczenia. Powinny być zastosowane do tego celu jedynie ultraczyste naczynia.

Zależnie od materiału filtra i analitu, filtry próbkujące są ekstrahowane w piecu mikrofalowym z zastosowaniem następujących mieszanek kwasów:

- kwasu azotowego $\mathrm{HNO}_{3}$

- mieszanki kwasu azotowego $\mathrm{HNO}_{3}$ i nadtlenka wodoru $\mathrm{H}_{2} \mathrm{O}_{2}$

- mieszanki kwasu azotowego, kwasu solnego $\mathrm{HCl}$ i nadtlenku wodoru $\mathrm{H}_{2} \mathrm{O}_{2}$

Wynikowe rozwiązania są poddane analizie z zastosowaniem ICPMS. Zależnie od analitu, stosuje się poczwórne ICPMS (ELAN 6000, Perkin Elmer/Sciex) lub ICPMS o wysokiej rozdzielczości (ELEMENT 2, Thermofinnigan).

Wiarygodne wyniki mogą być osiągnięte jedynie wtedy, gdy wyznaczona będzie granica dla całej procedury pomiarowej, włącznie z próbkowaniem, przygotowaniem próbki i analizą. Dlatego materiały wyjściowe nowego filtra i materiały powierzchniowo czyste (poddane przetwarzaniu w sposób najbardziej zbliżony do analizowanych filtrów),

Table 1. Test engine

Tabela 1. Silnik badawczy

\begin{tabular}{|l|c|c|}
\hline Manufacturer/producent & \multicolumn{2}{|c|}{ Liebherr } \\
\hline Type/rodzaj & D934S & D914T \\
\hline $\begin{array}{l}\text { Cylinder volume/objętość } \\
\text { cylindra }\end{array}$ & $6.36 \mathrm{dm}^{3}$ & $6.11 \mathrm{dm}^{3}$ \\
\hline $\begin{array}{l}\text { Rated velocity [rpm]/pręd- } \\
\text { kośc znamionowa [obr/min] }\end{array}$ & 1800 & 2000 \\
\hline $\begin{array}{l}\text { Rated power/znamionowa } \\
\text { moc użyteczna }\end{array}$ & $105 \mathrm{~kW}$ & $110 \mathrm{~kW}$ \\
\hline Model/model & 4 cylinder in-line/4 cylindry, rzędowy \\
\hline $\begin{array}{l}\text { Combustion process/proces } \\
\text { spalania }\end{array}$ & Direct injection/wtrysk bezpośredni \\
\hline $\begin{array}{l}\text { Injection pump/pompa } \\
\text { wtryskowa }\end{array}$ & \multicolumn{2}{|c|}{ Bosch unit pump/Bosch } \\
\hline $\begin{array}{l}\text { Supercharging/doladowanie } \\
\text { turbodot./IC }\end{array}$ & $\begin{array}{c}\text { TC/turbodolado- } \\
\text { wanie }\end{array}$ \\
\hline $\begin{array}{l}\text { Emission control/kontrola } \\
\text { emisji }\end{array}$ & EGR & 2005 \\
\hline Desinged/rok produkcji & \multicolumn{2}{|c|}{1995} \\
\hline
\end{tabular}


Table 2. Fuel: SN 181160-1:2005 Class D

Tabela 2. Paliwo: SN 181160-1:2005 klasa D

\begin{tabular}{|l|c|}
\hline Density (at $40^{\circ} \mathrm{C}$ )/gęstość & $0.820-0.845 \mathrm{~g} / \mathrm{ml}$ \\
\hline Viscosity $\left(\right.$ at $20^{\circ} \mathrm{C}$ )/ lepkość & $2.0-3.2 \mathrm{~mm} 2 / \mathrm{s}$ \\
\hline Flame point: min/punkt zapłonu: min & $62{ }^{\circ} \mathrm{C}$ \\
\hline Cloud point:max/punkt zmętnienia: $\max$ & $-10^{\circ} \mathrm{C}$ \\
\hline Filtering limit/granica filtrowania & CFPP max. $-20^{\circ} \mathrm{C}$ \\
\hline Coke residue/pozostałość koksowania & $\max .0 .02 \mathrm{~g} / 100 \mathrm{~g}$ \\
\hline Ash/popioły & vestigial/śladowe \\
\hline Sulfur/siarka & $\max .0 .0010 \mathrm{~g} / 100 \mathrm{~g}$ \\
\hline Cetane number/liczba cetanowa & $\min .52-54$ \\
\hline Boiling analysis/analiza wrzenia & $\min .98 \% \mathrm{obj}$. \\
\hline $\begin{array}{l}\text { Calorific value (lower)/wartość opałowa } \\
\text { (niższa) }\end{array}$ & $\min .42 .5 \mathrm{MJ} / \mathrm{kg}$ \\
\hline
\end{tabular}

Table 3. Lubricant: $15 \mathrm{~W} / 40$

Tabela 3. Olej smarujacy $15 \mathrm{~W} / 40$

\begin{tabular}{|l|c|c|}
\hline Property/właściwość & - & - \\
\hline Viscosity kin. $40^{\circ} \mathrm{C} /$ /lepkość kinematyczna & - & $\mathrm{mm} / \mathrm{s}$ \\
\hline Viscosity kin $100^{\circ} \mathrm{C} /$ lepkoś́ kinematyczna & 13.98 & $\mathrm{~mm} / \mathrm{s}$ \\
\hline Viscosity index/indeks lepkości & - & $(-)$ \\
\hline Density $20^{\circ} \mathrm{C} /$ gęstość dla $20^{\circ} \mathrm{C}$ & - & $\mathrm{kg} / \mathrm{m}^{3}$ \\
\hline Pourpoint/temperatura plynności & -25 & ${ }^{\circ} \mathrm{C}$ \\
\hline Flamepoint/punkt zaplonu & - & ${ }^{\circ} \mathrm{C}$ \\
\hline TBN & 8.4 & $\mathrm{mg} \mathrm{KOH} / \mathrm{g}$ \\
\hline Sulfur ashes/popioły siarkowe & 10770 & $\mathrm{mg} / \mathrm{kg}$ \\
\hline Sulfur/siarka & 3360 & $\mathrm{mg} / \mathrm{kg}$ \\
\hline $\mathrm{Mg}$ & $<10$ & $\mathrm{mg} / \mathrm{kg}$ \\
\hline $\mathrm{Zn}$ & 1200 & $\mathrm{mg} / \mathrm{kg}$ \\
\hline $\mathrm{Ca}$ & 2630 & $\mathrm{mg} / \mathrm{kg}$ \\
\hline $\mathrm{P}$ & 1110 & $\mathrm{mg} / \mathrm{kg}$ \\
\hline
\end{tabular}

However, an incredibly high peak occurs for very small particles in the size range $10-20 \mathrm{~nm}$. These are solid particles, which are not soot particles, and can only be ash particles. Probably, the lube oil consumption is high at the idling point. This because the blow-by gas flow, which pushes back the lubrication film, is much weaker. More lube oil and thus more metals infiltrate into the combustion and consequently into the emission spectrum. At idling, these very fine metal-oxide particles find few soot particles to ride on. The metal-oxide particles remain unattached and are observed as a high concentration. Many metal-oxide particles are also prevalent at other operating points. Deposited on larger soot particles, the metal-oxide particles remain undetected until composition is analyzed.

Figure $6 \mathrm{~b}$ is the data after the particle filter. Apparently, the filtration efficiency is almost independent of the particle size. The entire spectrum is suppressed about 3 orders of magnitude. Surprisingly, the peak at the idling point almost completely disappears. Diffusion dominated filters intercepts smaller particles even more efficiently than 100 nm particles.

Figure 7 illustrates the filtration characteristic using the parameter Penetration $=1-$ filtration efficiency. powinny być poddane procesowi próbkowania, roztwarzania i analizy.

Ryzyko zanieczyszczenia i występowania efektów pamięci ma duże znaczenie, zwłaszcza dla powszechnie spotykanych metali. Zazwyczaj wyznaczenie metalu jest ograniczone bardziej procedurą próbkowania i przygotowania próbki niż granicami wykrycia metody analitycznej [36]. Silniki badawcze, paliwo i olej smarujący przedstawiono $\mathrm{w}$ tablicach 1-3.

\section{Wyniki analizy wymiarowej wybranych metali zgodnie z testem VERT}

Pierwsze przedstawione wyniki dotyczą rozkładu wymiarowego cząstki z zastosowaniem SMPC, dla dwóch reprezentatywnych przypadków: $\mathrm{z}$ filtrem cząstek stałych i bez filtra. Procedurę PMP zastosowano do próbkowania realizowanego przed klasyfikacją wymiarową i pomiarem ilości cząstek. Procedura PMP obejmuje ogrzewanie spalin do temperatury $300{ }^{\circ} \mathrm{C}$, następnie rozcieńczenie w proporcji 1:100, tak że wszystkie lotne cząstki (krople) ulegają odparowaniu, dzięki czemu mierzone są tylko stałe cząstki. Test jest przeprowadzany w 8 punktach pracy, dla których tworzonych jest 8 charakterystyk częstotliwościowych SMPC (uwzględniają każdy przypadek badawczy). Tworzone są przynajmniej 3 obrazy dla każdej charakterystyki. Punkt 8 pracy odpowiada biegowi luzem dla niewielkich prędkości obrotowych.

Na rysunkach 6a i 6b przedstawiono wyniki z układu filtra cząstek z podłożem katalitycznym. Składnikiem ścianek filtra ceramicznego jest Fe, celem przyspieszenia procesu regeneracji układu z osadzonych cząstek sadzy. Dodatkowo analizowano emisję Fe. Znacząco (rys. 6a) dla 7 i 8 punktu pomiarowego rozkład wymiarowy cząstek jest jednorodny, niezależny od prędkości obrotowej i obciążenia. Jedynie dla biegu jałowego występuje inny rozkład. Badaniom emisji wtórnej poddano więcej niż 20 układów filtra cząstek stałych. Wszystkie prezentują te same wyniki: w zakresie biegu jałowego występuje nadmiar powietrza i w konsekwencji cząstek sadzy w objętości spalin. Typowa wartość maksymalna ilości sadzy dla rozmiaru $100 \mathrm{~nm}$ jest prawie niezauważalna w tej skali. Jednak duża wartość maksymalna pojawia się dla bardzo małych cząstek o wymiarach w przedziale $10-20$ nm. Cząstkami tymi są cząstki stałe nie- będące cząstkami sadzy, a tylko cząstkami popiołów. Najprawdopodobniej zużycie oleju smarującego osiąga dużą wartość dla biegu jałowego. Wynika to z przepływu gazu od przewietrzania skrzyni korbowej, który kieruje z powrotem film olejowy. Większa ilość oleju smarującego i w konsekwencji metali przedostaje się do komory spalania, dając większą wartość emisji na charakterystyce widmowej. Dla biegu jałowego powyższe małe cząstki tlenków metali odnajdują niewielką liczbę cząstek sadzy, na których osiadają. Cząstki tlenków metali pozostają niepołączone i są obserwowane w postaci dużej koncentracji. Wiele cząstek tlenków metali występuje również dla innych punktów pracy. Osadzone na większych cząstkach sadzy, cząstki tlenków metali pozostają niewykryte do czasu, gdy nie będzie oceniony ich skład. 

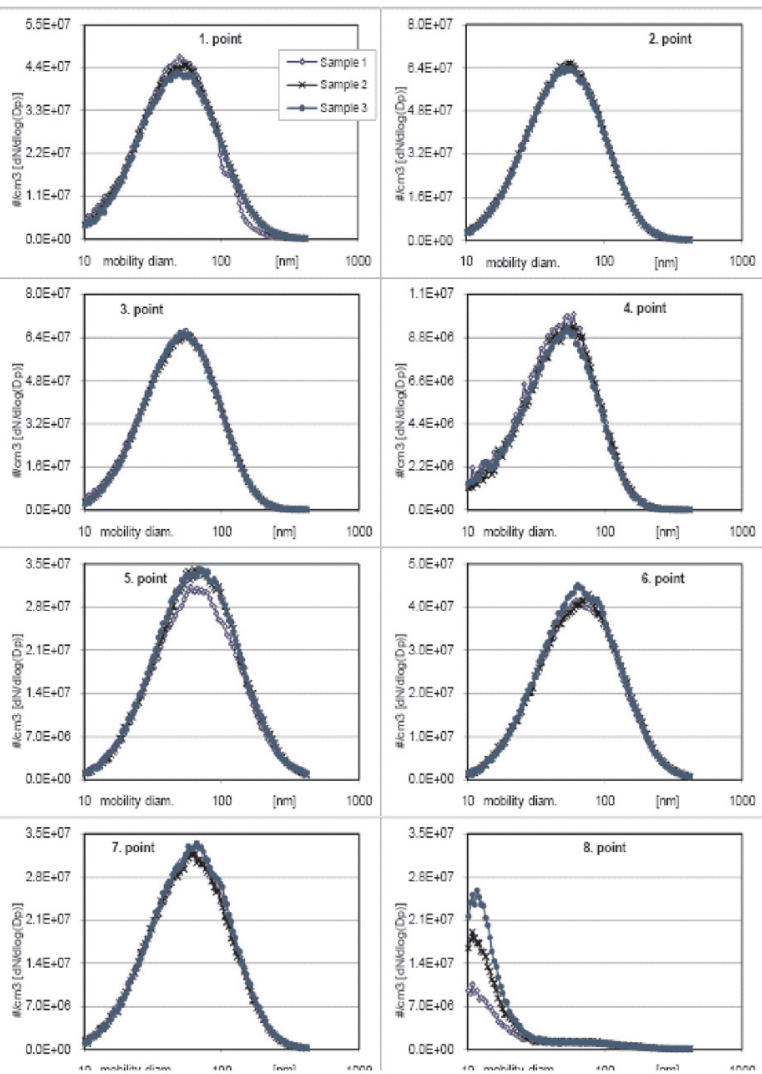

Fig. 6a. Fe coated particle filter. Measured before the particle filter. Engine is Liebherr 924

Rys. 6a. Filtr cząstek stałych pokryty Fe. Pomiar przed filtrem cząstek statych. Silnik Liebherr 924

These filtration characteristics facilitate interesting interpretations. The filtration characteristic, at high load and high space-velocity, is almost flat. Effective filtration occurs both in the diffusion range and also in the impaction range. The space velocity is much lower at the low idling point. The filtration curve then steepens. The conditions favor interception of the very small particles through diffusion. And impaction is less effective because of low space-velocity.

This investigation did not indicate that the coating sheds Iron particles.

Figure 8a shows data from an older engine, Liebherr 914, which clearly emits more particles. The engine is fitted with a very efficient filter. A Ferrocen based fuel additive is used. The catalyst is oxidized to $\mathrm{Fe}_{2} \mathrm{O}_{3}$ during combustion. The deployed FBC concentration in application is $<20 \mathrm{ppm}$. The tests were done at the higher Fe concentration of 40 ppm in the fuel to emphasize the effects. The FBC is dosed at constant concentration to the fuel. Thus, at high load points, many metal-oxide particles are released. Least FBC is dosed at idling. Nevertheless, here too a very high peak is observed in the range $10-20 \mathrm{~nm}$. These are partially the additive particles and partially the increasing ash particles.

Additive promoted regeneration is more effective than coatings [42]. This despite the higher FBC reaction temperature of $320{ }^{\circ} \mathrm{C}$ compared to $240{ }^{\circ} \mathrm{C}$ for Pt coated and $\mathrm{NO}_{2}$ induced regeneration. But $\mathrm{FBC}$ promotes oxygen induced regeneration. That is faster, more exothermic and thoroughly

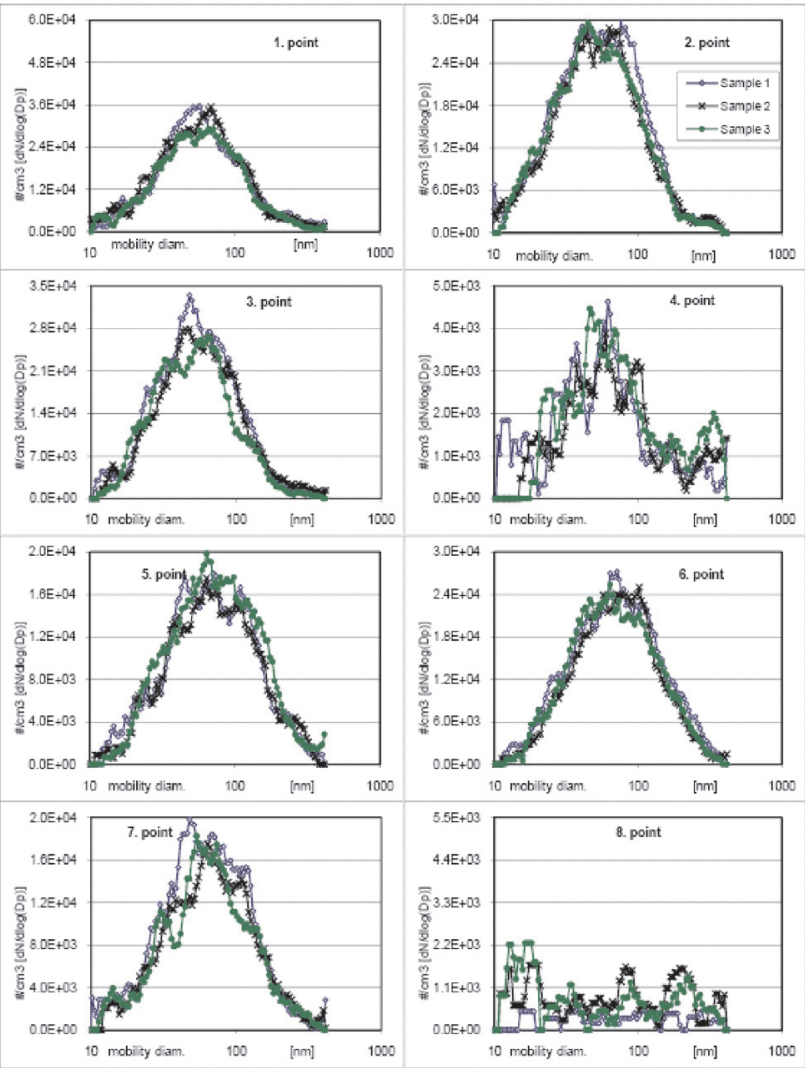

Fig. 6b. Fe coated particle filter. Measured after the particle filter. Engine is Liebherr 924

Rys. 6b. Filtr cząstek stalych pokryty Fe. Pomiar za filtrem cząstek statych. Silnik Liebherr 924

Na rysunku 6a przedstawiono dane uzyskane za filtrem cząstek stałych. Widać, iż sprawność procesu filtracji jest prawie niezależna od rozmiaru cząstki. Całe widmo jest ograniczone do 3 rzędów wielkości. Zadziwiające jest, iż wartość maksymalna dla biegu jałowego prawie zanika. Proces dyfuzji zdominował przejęcie przez filtry mniejszych cząstek nawet bardziej niż dla cząstek o rozmiarze $100 \mathrm{~nm}$.

Na rysunku 7 przedstawiono wykresy filtracji z zastosowaniem parametru: przenikanie $=1-$ sprawność filtracji.

Powyższe wykresy filtracji umożliwiają dokonanie interesujących interpretacji. Wykresy filtracji w zakresie dużego obciążenia i dużej prędkości obszarowej mają prawie płaski przebieg. Efektywny proces filtracji występuje zarówno w obszarze dyfuzji, jak i impakcji. Prędkość obszarowa jest znacznie mniejsza w zakresie biegu jałowego. Następnie krzywa filtracji wznosi się stromo. Warunki sprzyjają przechwytywaniu bardzo małych cząstek przez dyfuzję. Impakcja natomiast jest mniej efektywna z powodu małej prędkości obszarowej.

Powyższe badanie nie wykazało, że powłoka traci cząstki żelaza.

Na rysunku 8a zaprezentowano dane dla starszej konstrukcji silnika Liebherr 914, który emituje więcej cząstek. Silnik wyposażono w filtr o dużej sprawności. Zastosowano dodatek paliwa oparty na ferrocenie. Katalizator jest utleniany podczas spalania do $\mathrm{Fe}_{2} \mathrm{O}_{3}$. Rozmieszczo- 


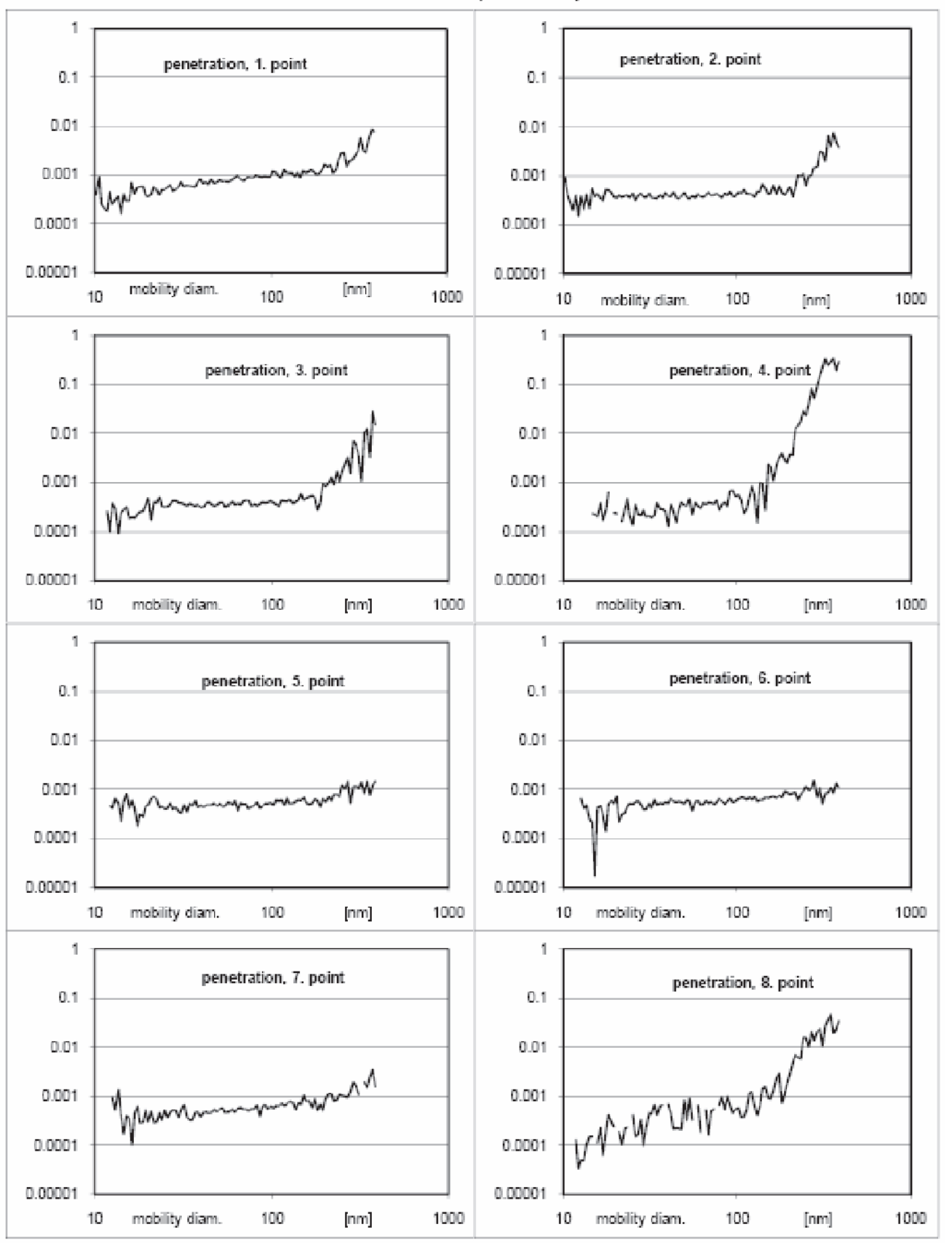

Fig. 7. Penetration at the 8 operating points of the Fe- coated filter, calculated from Fig. $6 \mathrm{a}$ and $6 \mathrm{~b}$

Rys. 7. Przenikanie w 8 punktach pomiarowych dla filtra pokrytego Fe, obliczone na podstawie rys. $6 a$ i $6 b$

na koncentracja FBC w praktyce jest $<20 \mathrm{ppm}$. Badania przeprowadzono dla większych stężeń $\mathrm{Fe}$ w paliwie równych $40 \mathrm{ppm}$, celem położenia nacisku na wyniki. FBC jest dozowane do paliwa przy stałym jego udziale. Oznacza to, iż dla punktów pracy w zakresie wysokich obciążeń uwalnianych jest wiele cząstek tlenków metali. Najmniejsza ilość FBC jest dozowana dla biegu luzem. Mimo tego tutaj również bardzo duży wzrost wartości maksymalnej jest obserwowany w zakresie $10-20 \mathrm{~nm}$. Powyższe cząstki stanowią cząstki dodatku i częściowo wzrastającą ilość cząstek popiołów.

Dodatek wspomagający regenerację jest bardziej efektywny niż podłoża [42]. Powoduje to, pomimo wyższej temperatury reakcji FBC równej $320{ }^{\circ} \mathrm{C}$ w porównaniu do $240{ }^{\circ} \mathrm{C}$ dla podłoża Pt i NO${ }_{2}$, wymuszenie regeneracji. FBC wspomaga wymuszoną tlenem regenerację. Proces ten jest szybszy, bardziej egzotermiczny i powoduje gruntowne oczyszczenie filtra.

Dodatki Fe są niezależne od zawartości siarki w paliwie i nie zmniejszają $\mathrm{NO}_{2}$. Dodatki nie

cleans the filter. Fe additives are independent of the fuel's sulfur content and do not release $\mathrm{NO}_{2}$. Additives intrinsically do not age. Moreover, variable dosage facilitates elegant adaptation to practical requirements.

The disadvantages of additives are ash clogging the filter and the risk of metal-oxide particle emissions. VERT therefore requires the filter to substantially intercept the emission of additive particles. When a $\mathrm{Fe}$ additive is used, the $\mathrm{Fe}$ emissions must be less than the raw $\mathrm{Fe}$ emission of the engine.

Figure $8 \mathrm{~b}$ shows the size distribution after the particle filter. The concentration numbers $10^{3}-10^{4}$ are almost equivalent to ambient air. The instrumentation is at the detection limit and hence the scatter. The filter diminishes emissions ulegają starzeniu. Ponadto zmienne dozowanie ułatwia właściwą adaptację do warunków rzeczywistych.

Do wad tych dodatków należy zatykanie filtra popiołami i niebezpieczeństwo emisji cząstek tlenków metali. Dlatego VERT wymaga od filtra przechwycenia cząstek dodatków celem zmniejszenia ich emisji w spalinach. W sytuacji stosowania dodatku Fe, emisja tego metalu musi być mniejsza niż pierwotna emisja $\mathrm{Fe}$ w spalinach silnika

$\mathrm{Na}$ rysunku 8 b przedstawiono rozkład wymiarowy cząstek za filtrem cząstek stałych. Wartości stężenia na poziomie $10^{3}-10^{4}$ odpowiadają w przybliżeniu wartościom dla powietrza atmosferycznego. 


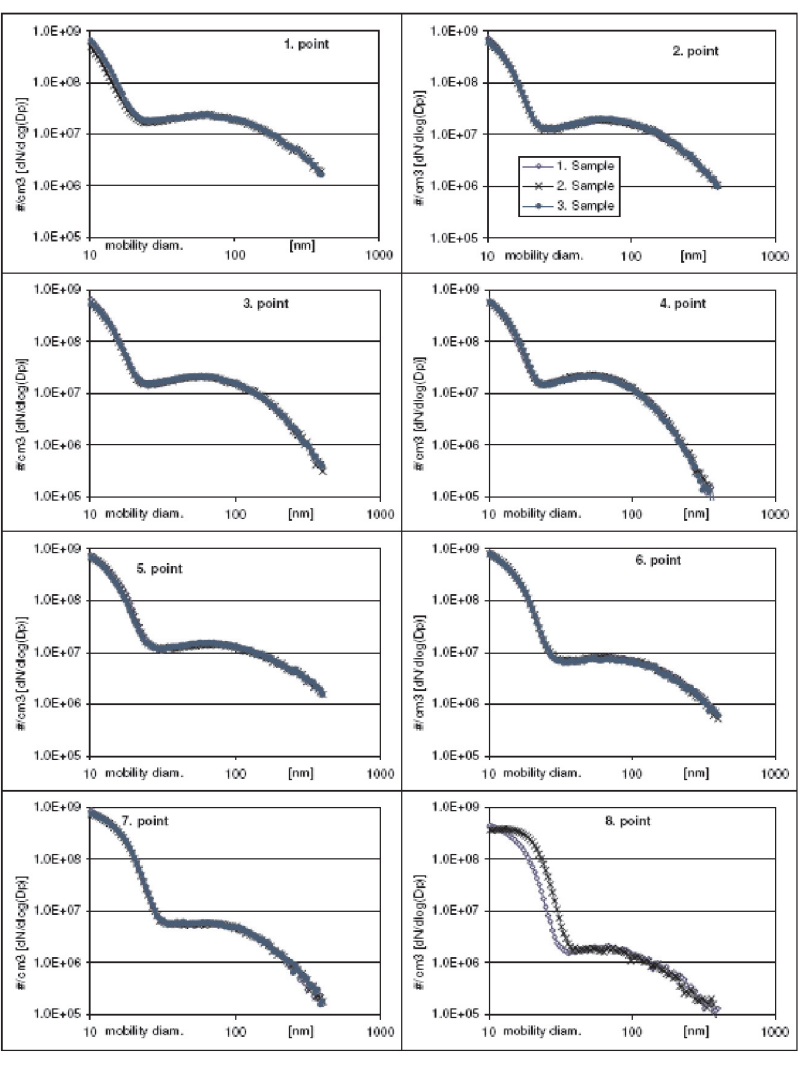

Fig. 8a. Uncoated particle filter operated with $40 \mathrm{ppm} \mathrm{Fe}$ additive to promote regeneration. Measured before the particle filter. Engine is Liebherr 914

Rys.8a. Filtr czastek stalych bez warstwy pokrywajacej, pracujacy $z$ dodatkiem 40 ppm Fe w celu wsparcia regeneracji. Pomiar przed filtrem cząstek statych. Silnik Liebherr 914

by about 3 orders of magnitude. The high peak of additive dosage, too, is diminished about $3-4$ orders of magnitude, but remains visible.

Figure 9 plots the penetration filter characteristic of Fe additive at very high concentrations. The filtration efficiency exceeds $99.99 \%$ and the penetration curves are very balanced. Nevertheless, some ash particles are penetrating the filter. The reasons are a too high space velocity: Only a lower space-velocity can compensate the rather coarse $20-30 \mu \mathrm{m}$ pores in this filter system.

Such filters must be redesigned for smaller pore size and more compact pore distribution.

After the online investigation, the polycarbonate collector foils from the ELPI impactor were sent for the metal analysis described in the previous section. The results are summarized in Tables 4 and 5.

Table 4 shows the emissions measured during the 200 minutes test. Ahead of the filter, the engine Fe emission was $1.88 \mu \mathrm{g}$. After the filter it was $0.77 \mu \mathrm{g}$. Despite the filter's Fe coating and consequent possible Fe release, the tailpipe Fe emissions are substantially lower than the engine's raw Fe emissions by $60 \%$.

Table 5 shows data for the particle filter system operated with the Fe additive FBC. Three measurements were done. These are the 1) baseline raw emissions without the filter

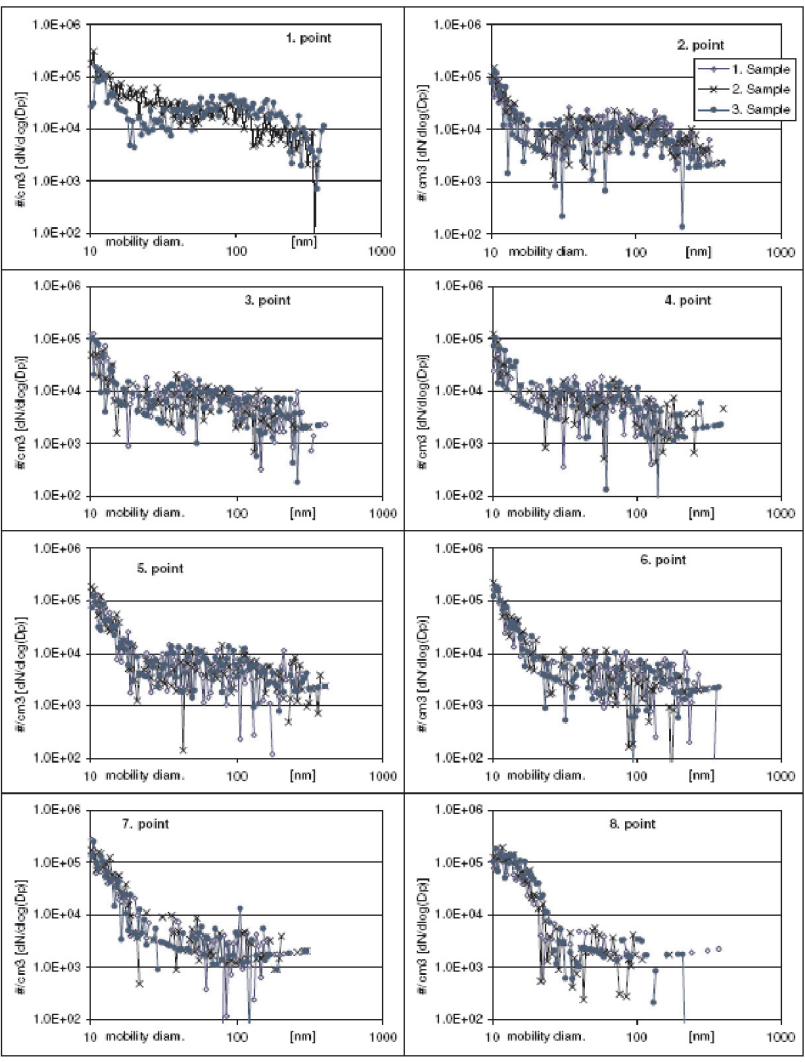

Fig. 8b. Uncoated particle filter operated with 40 ppm Fe additive to promote regeneration. Measured after the particle filter. Engine is Liebherr 914

Rys.8b. Filtr czastek statych bez warstwy pokrywajacej pracujacy z dodatkiem 40 ppm Fe w celu wsparcia regeneracji. Pomiar za filtrem czastek stałych. Silnik Liebherr 914

Oprzyrządowanie jest ustawione na wartość graniczną wykrycia, stąd występuje rozproszenie. Filtr zmniejsza emisje o około 3 rzędy wielkości. Również duża wartość maksymalna dawki dodatku zmniejsza się o około 3 - 4 rzędy wielkości, lecz pozostaje widoczna.

Rysunek 9 dotyczy wykresu przenikania filtra dodatkiem Fe dla bardzo dużych stężeń. Sprawność procesu filtracji przekracza 99,99\%, a przebiegi krzywych przenikania są bardzo ustabilizowane. Mimo tego niewielka ilość cząstek popiołów przenika do filtra. Powodem jest zbyt duża prędkość obszarowa: jedynie mniejsza prędkość obszarowa może zrównoważyć duże rozmiary por, równe $20-30 \mu \mathrm{m}$, występujące w układzie filtra. Takie filtry muszą być ponownie zaprojektowane pod kątem uzyskania mniejszych rozmiarów por i bardziej zwartego ich rozkładu.

Po wykonaniu ciągłych pomiarów poliwęglanowe folie kolektora od impaktora ELPI były kierowane do analizy składu metali, którą opisano w poprzednim rozdziale $\mathrm{W}$ tabelach 4 i 5 zamieszczono wyniki uzyskane z pomiarów.

Na rysunku 4 przedstawiono emisję zmierzoną w teście o okresie trwania równym 200 minut. Emisja Fe z silnika zmierzona przed filtrem wyniosła $1,88 \mu \mathrm{g}$, podczas gdy za filtrem osiągnęła wartość $0,77 \mu \mathrm{g}$. Mimo podłoża Fe filtra i wynikającego z tego uwolnienia Fe, emisje Fe w przewodzie 


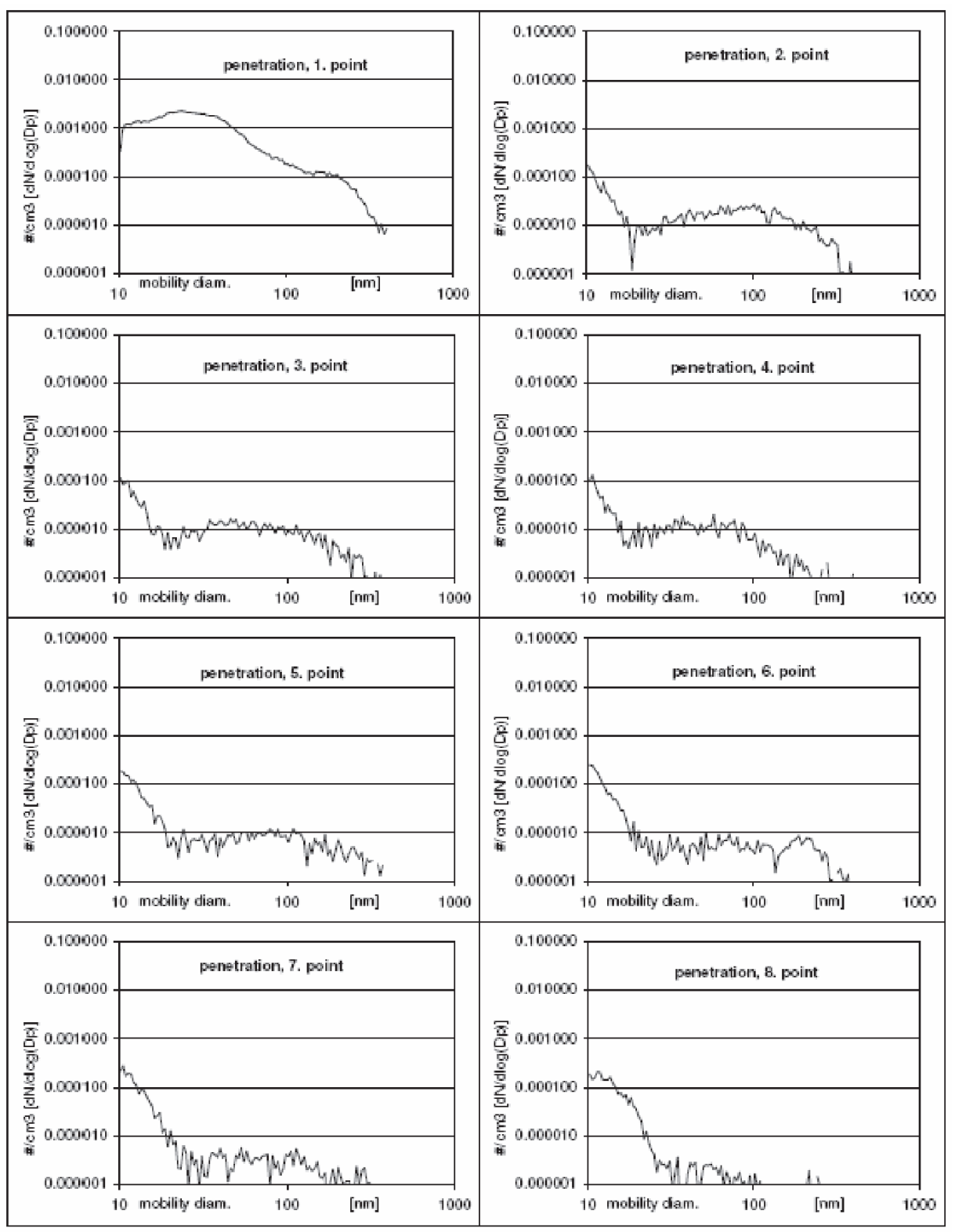

Fig. 9. Penetration at the 8 operating points with Fe additive, calculated from Fig. $8 \mathrm{a}$ and $8 \mathrm{~b}$ Rys. 9. Przenikanie w 8 punktach pomiarowych dla filtra z dodatkiem Fe, obliczone z rys. 8 a $i$ 8b wylotowym silnika są mniejsze o $60 \%$ niż pierwotne emisje Fe $\mathrm{z}$ silnika.

W tabeli 5 zaprezentowano wyniki dla systemu filtra cząstek stałych pracującego na dodatku FBC opartego na Fe. Dokonano trzech pomiarów: 1) bazowa emisja pierwotna bez filtra i FBC (RO $80)$, 2) emisja pierwotna $z$ dodatkiem Fe (EO-81) i 3) stężenie Fe zmierzone za filtrem.

Stężenie Fe w gazie nierozcieńczonym w sposób naturalny wzrosło wraz z zastosowaniem dodatku Fe. Filtr umożliwia zmniejszenie emisji Fe znacznie poniżej poziomu emisji pierwotnej silnika.

Powyższe pomiary są reprezentatywne dla grupy ponad 20 badanych filtrów. Filtr zapasowy ELPI wychwytuje większość z cząstek o wymiarach $<30 \mathrm{~nm}$. Jednakże analiza filtra zapasowego (kwarcowego) jest mniej precyzyjna aniżeli filtrów stopniowych ELPI (poliwęglanowy). Fe jest również wykrywany dla większych klas wymiarowych ELPI. Cząstki Fe są nieduże. Niewielkie cząstki Fe są rozmieszczone na większych cząstkach sadzy i łącznie zgromadzone na odpowiednim stopniu impaktora.

Metoda ELPI nie jest doskonała do rozróżnienia osadzonych i nieosadzonych cząstek Fe. Większość cząstek Fe ma małe rozmiary. and without FBC (RO 80), then 2) the raw emission with the Fe additive (EO-81) and finally 3 ) the Fe concentration measured after the filter.

The Fe concentration in the raw gas is naturally increased through the Fe additive. The filter succeeds in curtailing Fe emissions much below the level of the engine's raw emission.

These measurements are representative for those from over 20 filter systems. The ELPI backup filter intercepts most of the finest particles sized $<30 \mathrm{~nm}$. However, the analysis of the backup filter (quartz) is less precise than the ELPI stage filters (polycarbonate). Fe is also detected in bigger ELPI size classes. The Fe particles are intrinsically not large. Instead, small Fe particles are deposited on larger soot particles and jointly collected on the corresponding impactor stage. The ELPI method is not ideal to distinguish

\section{Problem migracji}

Cząstki zatrzymywane są w porowatej osnowie filtra w wyniku dyfuzji lub impakcji. Siły van der Waalsa przytwierdzają przechwycone cząstki do porowatej powierzchni. Przytwierdzenie jest silniejsze dla małych cząstek. W związku z tym niewielkie cząstki popiołów raz przytwierdzone jest trudno usunąć, nie z zastosowaniem zjawisk aerodynamicznych. Bardzo duże scalone cząstki popiołów są bardziej podatne na opuszczenie osnowy filtra

Sytuacja jest niekorzystna dla cząstek popiołów, zwłaszcza tych addytywnych osadzonych na cząstkach sadzy i uwięzionych jako aglomeraty wewnątrz osnowy filtra. Jeżeli taki filtr jest regenerowany, tzn. sadza ulega spaleniu, wówczas cząstki tlenków metali są nagle porywane przez strumień gazu i kierowane ku wyjściu z filtra, chyba iż ma miejsce dalsza filtracja. Wybrana emisja cząstek metali 
Table 4. Size analysis for Fe particles from a particle filter system with Fe coating

Tabela 4. Analiza wymiarowa dla czastek Fe systemu filtra czastek statych $z$ warstwa $F e$

\begin{tabular}{|c|c|c|c|}
\hline ELPI Stage/etap ELPI & $\begin{array}{c}\text { Size class } \\
\text { D 50\%/klasa } \\
\text { wymiaru D 50\% }\end{array}$ & RO-120 & RF2-122 \\
\hline & {$[\mu \mathrm{m}]$} & [ $\mu \mathrm{g} /$ filter $]$ & [ $\mu \mathrm{g} /$ filter] \\
\hline $\begin{array}{l}\text { Backup filter/filtr zapa- } \\
\text { sowy }\end{array}$ & $<0.03$ & 1.39 & 2.44 \\
\hline 1 & 0.03 & 0.08 & 0.04 \\
\hline 2 & 0.06 & 0.26 & 0.07 \\
\hline 3 & 0.11 & 0.11 & 0.04 \\
\hline 4 & 0.17 & 0.11 & 0.04 \\
\hline 5 & 0.27 & 0.14 & 0.10 \\
\hline 6 & 0.41 & 0.13 & 0.12 \\
\hline 7 & 0.66 & 0.17 & 0.03 \\
\hline 8 & 1.02 & 0.15 & 0.07 \\
\hline 9 & 1.65 & 0.15 & 0.08 \\
\hline 10 & 2.52 & 0.15 & 0.07 \\
\hline 11 & 4.08 & 0.18 & 0.05 \\
\hline 12 & 6.56 & 0.25 & 0.07 \\
\hline Sum/suma & & 1.88 & 0.77 \\
\hline $\begin{array}{c}\text { Detection Limit/ granicz- } \\
\text { na wartość możliwa do } \\
\text { wykrycia }\end{array}$ & 0.0001 & - & - \\
\hline $\begin{array}{c}\text { Average blanks ELPI } \\
\text { filters/wartość średnia dla } \\
\text { filtrów ELPI }\end{array}$ & 0.070 & - & - \\
\hline $\begin{array}{l}\text { Average blanks backup } \\
\text { filters/wartość średnia dla } \\
\text { filtrów zapasowych }\end{array}$ & 0.85 & - & - \\
\hline
\end{tabular}

RO-120: before particle filter/przed filtrem czastek statych RF2-122: after particle filter/za filtrem czastek statych
Table 5. Size analysis for Fe particles from a particle filter system with Fe additive e

Tabela 5. Analiza wymiarowa dla czastek Fe z systemu filtra czastek statych $z$ dodatkiem $\mathrm{Fe}$

\begin{tabular}{|c|c|c|c|c|}
\hline $\begin{array}{c}\text { ELPI Stage/ } \\
\text { etap ELPI }\end{array}$ & $\begin{array}{c}\text { Size class } \\
\text { D 50\%/klasa } \\
\text { wymiaru D 50\% }\end{array}$ & EO-80 & EO-81 & EF-82 \\
\cline { 2 - 5 } & {$[\mu \mathrm{m}]$} & {$[\mu \mathrm{g} /$ filter $]$} & {$[\mu \mathrm{g} /$ filter $]$} & {$[\mu \mathrm{g} /$ filter $]$} \\
\hline $\begin{array}{c}\text { Backup/ } \\
\text { pomocniczy }\end{array}$ & $<0.03$ & - & - & - \\
\hline 1 & 0.03 & 0.08 & 8.6 & 0.12 \\
\hline 2 & 0.06 & 0.06 & 18.2 & 0.07 \\
\hline 3 & 0.11 & 0.11 & 12.8 & 0.20 \\
\hline 4 & 0.17 & 0.08 & 6.4 & 0.07 \\
\hline 5 & 0.27 & 0.13 & 4.6 & 0.07 \\
\hline 6 & 0.41 & 0.29 & 4.2 & 0.08 \\
\hline 7 & 0.66 & 0.31 & 4.0 & 0.10 \\
\hline 8 & 1.02 & 0.30 & 3.0 & 0.11 \\
\hline 9 & 1.65 & 0.17 & 0.91 & 0.04 \\
\hline 10 & 2.52 & 0.54 & 0.62 & 0.04 \\
\hline 11 & 4.08 & 0.11 & 0.46 & 0.13 \\
\hline 12 & 6.56 & 0.15 & 0.28 & 0.07 \\
\hline Sum/suma & & 2.33 & 64.07 & 1.10 \\
\hline DL & 0.003 & & & \\
\hline $\begin{array}{c}\text { Average } \\
\text { blanks ELPI } \\
\text { filters/ wartość } \\
\text { średnia dla } \\
\text { filrów ELPI }\end{array}$ & 0.01 & - & - & - \\
\hline
\end{tabular}

EO-81: before particle filter baseline without dosage/przed filtrem cząstek statych bez dodatku

EO-82: before particle filter with 40 ppm Fe dosage/przed filtrem czastek statych $z$ dodatkiem Fe o stężeniu równym 40 ppm

EF-82: after particle filter with 40 ppm Fe dosage/za filtrem czastek stalych przy dodatku Fe równym 40 ppm

between attached and unattached $\mathrm{Fe}$ particles. Most of the Fe particles are definitely very small.

\section{The migration problem}

Particles are intercepted in the porous filter matrix through diffusion or impaction. The van der Waals forces bind the intercepted particles to the pore surface. The binding is stronger for small particles. Hence, small ash particles once attached are difficult to remove and certainly not through aerodynamic effects. Very large agglomerated ash particles are more likely to eventually escape the filter matrix.

The situation is critical for ash particles, especially those additive particles deposited on soot particles and trapped as agglomerates inside the filter matrix. When such a filter is regenerated, i.e. the soot in the cake burns, then the

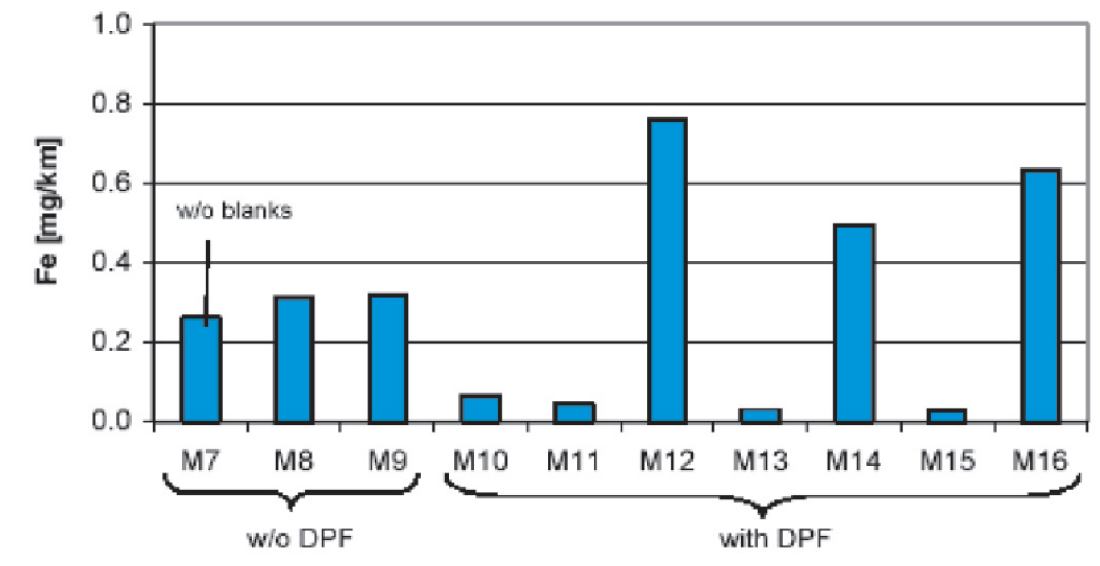

Fig. 10. Fe emissions per km in the EUDC cycle; M7, M8, M9 without particle filter; M10, M11, M13, M15 with particle filter, no regen; M12, M14, M16 regeneration after every 50 accumulation cycles

Rys. 10. Emisja Fe w teście EUDC w [mg/km]; M7, M8, M9 bez filtra cząstek statych; M10, M11, M13, M15 z filtrem czastek statych, bez regeneracji; M12, M14, M1 regeneracja po każdych sukcesywnych cyklach 
metal oxide particles are suddenly entrained in the flow and escape, unless further filtration occurs. Some emission of metal-oxide particles is a hazard during filter regeneration. This release can happen even from filters that possess very high filtration efficiency and that do not release soot during regeneration.

A pertinent investigation was done on a system operated with $20 \mathrm{ppm}$ Fe additive. After every 50 EUDC cycles, the exhaust-gas temperature was raised to trigger regeneration. Figure 10 depicts the results.

The cycles M7 until M9 are typical emissions without filter. M10, M11, M13 and M15 are the metal-oxide particle emissions between the regenerations, averaged over $50 \mathrm{cy}$ cles. These emissions are at the edge of the detectable range. M12, M14 and M16 are regenerations during an EUDC cycle after accumulation during 50 EUDC cycles.

The emission during the regeneration is exceptionaly high. It is double the raw emissions. However, this influence after scaling down from 50 cycles, only represents a Fe emission of about $0.01 \mathrm{mg} / \mathrm{km}$. This effect is always prevalent. High space velocity and large pores exacerbate the Fe emissions. Efforts must be made to prevent or diminish it. Membrane filter technology [47] would be ideal.

\section{Conclusion}

Traffic generated particle emissions are generally recognized [47] as the worst air pollutant. Drastic technical countermeasures are required. The culprits can be the carbon in the soot, or the organic deposits on the soot particles, or the metal oxide particles. The definitive cause is yet unclear. Much evidence points to engine emitted metal-oxide particles (besides metal abrasion from brake and clutch linings [51]). If so, then not only Diesel engines but also SI engines must be scrutinized.

No emerging engine technology substantially diminishes these high emissions. Even hydrogen combustion does not diminish the hazard.

There are only two ways to rectify the problem. Firstly, deploy highly efficient particle filters on all combustion engines. Secondly, diminish the metal content of the lubrication oil. Both countermeasures are feasible. The efficacy of diminishing the metal content of lube oil is proven [37]. The filtration of ash particles from SI engines, using wall-flow catalytic converters is pragmatic $[38,39]$.

The emission curtailment concept requires that, after implementing the particle count, the toxic substances must be named. Hence, the metal content of the particles must be determined and limited. That will curtail the toxicity of the exhaust-gases.

Paper reviewed/Artykut recenzowany stanowi ryzyko podczas procesu regeneracji. Powyższe uwolnienie może występować nawet dla filtrów mających wysoką sprawność filtracji tych nieuwalniających sadzy podczas regeneracji.

Odpowiednie badanie przeprowadzono dla systemu pracującego na dodatku Fe o stężeniu 20 ppm po każdych 50 cyklach EUDC; temperatura spalin była zwiększana w celu uruchomienia procesu regeneracji filtra cząstek stałych. Wyniki zaprezentowano na rys. 10. Cykle od M7 do M9 stanowily typowe cykle badania emisji bez filtra. Cykle M10, M11, M13 i M15 stanowią cykle pomiaru emisji cząstek tlenków metali pomiędzy regeneracjami, uśrednione z ponad 50 cykli. Powyższa emisja jest na granicy wykrywalnego zakresu. Cykle M12, M14 i M16 stanowią regeneracje uzyskane podczas testu EUDC po po nagromadzeniu danych z 50 cykli EUDC.

Emisja podczas procesu regeneracji jest wyjątkowo wysoka. Stanowi podwojoną wartość emisji pierwotnej. Jednakże rozważany wpływ po wyskalowaniu z 50 cykli reprezentuje emisję Fe o wartości jedynie około 0,01 $\mathrm{mg} / \mathrm{km}$. Powyższy wynik jest powszechnie uzyskiwany. Wysoka wartość prędkości objętościowej i duże rozmiary por zwiększają emisję Fe. Wszelkie wysiłki muszą być poczynione w celu zapobieżenia lub zmniejszenia powyższej emisji.

\section{Wnioski}

Emisja cząstek stałych w ruchu ulicznym jest uważana [47] za największe źródło zanieczyszczenia powietrza (wymagane są drastyczne środki zaradcze). Sprawcami mogą być węgiel w sadzy lub organiczne osady na cząstkach sadzy lub cząstki tlenków metali. Jednoznaczna przyczyna jest nadal nieznana. Znaczna liczba dowodów wskazuje na emitowane przez silnik cząstki tlenków metali (poza zużyciem metali od procesu hamowania i okładzin sprzęgła [51]). Jeżeli tak, wówczas nie tylko silniki o zapłonie samoczynnym, ale również o iskrowym muszą być brane pod uwagę.

Żadna nowa technologia silnikowa nie obniży istotnie tak dużych emisji. Nawet spalanie wodoru nie zmniejsza ryzyka dużych emisji.

Skorygowanie rozważanego problemu może być zrealizowane jedynie za pomocą dwóch sposobów. Po pierwsze, przez zainstalowanie wysokosprawnych filtrów cząstek stałych we wszystkich silnikach. Po drugie, zmniejszenie zawartości metalu w oleju smarującym. Oba środki zaradcze są możliwe do zastosowania. Potwierdzona została skuteczność zmniejszania zawartości metalu w oleju smarującym [37]. Proces filtracji cząstek popiołów w silnikach o zapłonie iskrowym przez wykorzystanie reaktorów katalitycznych z przepływem przyściennym jest działaniem pragmatycznym $[38,39]$.

Koncepcja ograniczenia emisji wymaga, aby po wprowadzeniu pomiaru liczby cząstek nazwać składniki toksyczne. Dlatego też zawartość metalu w cząstce stałej musi być wyznaczona i limitowana. Dzięki temu możliwe będzie zmniejszenie toksyczności gazów spalinowych. 


\section{Nomenclature/Skróty i oznaczenia}

AVL AVL GmbH, Austria www.avl.com

BC Black Carbon/grafit

BET en.wikipedia.org/wiki/BET_theory

CARB California Air Resources Board/Kalifornijska Rada ds. Zasobów Powietrza

CFPP Cold Filter Plugging Point/punkt zablokowania zimnego filtra

CNG Compressed Natural Gas/sprężony gaz ziemny

CVS Constant Volume Sampler/układ o stałej objętości próbki do rozcieńczania spalin, stosowany $w$ badaniach certyfikacyjnych emisji spalin

DPF Diesel Particle Filter/filtr czastek statych

EGR Exhaust Gas Recirculation/recyrkulacja spalin

ELPI Electrical Low Pressure Impactor/elektryczny niskociśnieniowy impaktor umożliwiajacy pomiar w czasie rzeczywistym rozkładu wymiarowego cząstek $i$ ich stężenie

EUDC Extra Urban Driving Cycle/europejski pozamiejski test jezdny

FBC Fuel Borne Catalyst/dodatek katalityczny stosowany do filtrów czastek statych
HDV Heavy Duty Vehicle/ciężki pojazd samochodowy

ICPMS Inductive Coupled Plasma Mass Spectroscopy/spektroskopia masowa z zastosowaniem sprzężonej plazmy

LDV Light Duty Vehicle/lekki uzytkowy pojazd samochodowy

PMP Particle Measurement Program/program pomiaru cząstek statych

RPM Revolutions per minute/prędkość obrotowa

SI Spark Ignition Engines/silniki o zapłonie iskrowym

SMPS Scanning Mobility Particle Sizer/skaningowy analizator wymiarowy cząstek stałych oparty na analizie ruchliwości elektrycznej czastek

TC,EC Total Carbon, Elemental Carbon/całkowita ilość węglowodorów, węgiel elementarny

VERT Project to curtail Diesel engines emissions in tunnel sites/ europejski projekt ograniczenia emisji z silników o zapłonie samoczynnym w obszarze tuneli

VOC Volatile Organic Compounds/lotne substancje organiczne

WHO World Health Organization/Światowa Organizacja Zdrowia

\section{Bibliography/Literatura}

[1] Ultrafeine (Aerosol)-Teilchen und deren Agglomerate und Aggregate, Grundsatzpapier des Deutschen Berufsgenossenschaftlichen Instituts für Arbeitssicherheit BIA, 20.5.1998.

[2] Kasper M. et al.: PM10-TEQ, Approach to a Health-Oriented Descriptor of Particulate Air Pollution, 11 th ETH Conference on Combustion Generated Nanoparticles, August 2007.

[3] Hinds W.C. : Aerosol Technology, Properties, Behavior, and Measurement of Airborne Particles, John Wiley \& Sons, ISBN 0-471-08726-2, 1889.

[4] Gehr P., Heyder J.: Particle-Lung Interactions, Marcel Dekker, Inc., New York - Basel, ISBN: 0-8247-9891-0.

[5] Daunderer M.: Metallvergiftungen, Diagnostik und Therapie, Kompendium der Klinischen Toxikologie, ecomed, ISBN 3-609-63700-5.

[6] Oberdörster G. et al.: Nanotoxicology: An Emerging Discipline Evolving from Studies of Ultrafine Particles, Enviromental Health Perspectives, volume 113, number Juli 2005.

[7] Gatti M.: Impact on health by nanoparticles created by high temperature explosions, 8th ETH Conference on Combustion Generated Nanoparticles, August 2004.

[8] Costantini M./HEI, An Evaluation of the health risk of using a cerium-based diesel fuel additive in conjunction with a particular filter, 5th ETH Conference on Nanoparticle Measurement, July 2001.

[9] Costantini M./HEI, Relation between particle metal content (with focus on iron) and biological responses, 4th ETH Conference on Nanoparticle Measurement, August 2000.

[10] Limbach L.K. et al.: Exposure of Engineered Nanoparticles to Human Lung Epithelial Cells: Influence of Chemical Composition and Catalytic Activity on Oxidative Stress, Environmental Science \& Technology, November 2007.

[11] Uptake and Inflammatory Effects of Nanoparticles in a Human Vascular Endothelial Cell Line, HEI Synopsis of Research Report 136, 2009.
[12] Gojova A. et al.: Induction of Inflammation in Vascular Endothelial Cells by Metal Oxide Nanoparticles: Effect of Particle Composition, Environmental Health Perspectives, volume 115, March 2007.

[13] Dick C.A.J. et al.: The Role of Free Radicals in the Toxic and Inflammatory Effects of Four Different Ultrafine Particle Types, Inhalation Toxicology, International Forum for Respiratory Research, 15.1, 39-52, link: http://dx.doi. org/10.1080/08958370304454.

[14] Heeb N., empa: Effects of low- and high-oxidation DPFs on genotoxic exhaust constituents, 13th ETH Conference on Nanoparticle Measurement, June 2009.

[15] Consultation on guidelines for metals and metalloids in ambient air for the protection of human health, defra, May 2008, Quelle www.defra.gov.uk/corporate/consult/metalsmetalloids

[16] Stöger T.: Particle related inflammation as results from oxidative stress caused by particle surface properties and/or bioavailability of organic compounds, 11th ETH Conference on Nanoparticle Measurement, August 2007.

[17] Hannoschöck N.: Kolbenringschmierung und -Verschleiss, Dissertation ETH Nr. 7635, Zürich 1984.

[18] Eberle K.: Linear Wear of a Two-Stroke Diesel Engine Operated at Very High Temperatures, Pressures and Reduced Cylinder Lubricant Feed Rates, ETH Zürich, CIMAG 1989.

[19] Hardenberg H.: Schwefelarmer Dieselkraftstoff für Stadtverkehrsfahrzeuge, Der Nahverkehr 3/87.

[20] Hildemann L.M.: Chemical Composition of Emissions from Urban Sources of Fine Organic Aerosol, Environ. Sci.Technol., Vol. 25, No. 4/1991.

[21] Israël G.W. et al.: Analyse der Herkunft und Zusammensetzung der Schwebestaubimmission, VDI Fortschritt-Berichte, Umwelttechnik Nr. 92. 
[22] Bockhorn H. et al.: In-situ berührungslose Bestimmung der Grössenverteilung nanoskaliger Metallteilchen, Abschlussbericht des Forschungsvorhabens 2442, Max Buchner-Stiftung, 2004.

[23] Griguli U., Sander H.: Wärmeleitung, Springer Berlin und New York, 1979.

[24] Hu S., Ayala A. et al.: Metals emitted from heavy-duty diesel vehicles equipped with advanded PM and NOx emission controls, Atmospheric Environment 43 (2009).

[25] Miller A.I.: The Origin and Fate of Metals during Diesel Engine Combustion, Dissertation University of Minnesota, 2005.

[26] Gautam M.: Issues in Measurement of Particle Size Distribution from In-Use Heavy-Duty Vehicles, ETH Conference on Nanoparticle Measurement, 2002.

[27] Grütering U.F. et al.: Bilanzierung von Motorölkomponenten bei einem PKW-Dieselmotor mit Abgasnachbehandlungs-system, 15. Aachener Kolloquium Fahrzeug- und Motorentechnik 2006.

[28] Miller A.L. et al.: Role of Lubrication Oil in Particulate Emissions from a Hydrogen-Powered Internal Combustion Engine, Environ. Sci. Technol., 41, 19, 6828-6835, 2007, 10.1021/ es070999r.

[29] Hill R.F., Mayer W.J.: Radiometric Determination of Platinum and Palladium attrition from automotive catalysts. Transactions on nuclear science, 1977.

[30] Edelmetall-Emissionen, GSF-Forschungszentrum für Umwelt und Gesundheit GmbH, Projektträger "Umwelt- und Klimaforschung", Abschlusspräsentation 17./18. Oktober 1996, Hannover.

[31] Gidney J.T., Twigg M., Kittelson D.: Effect of Organometallic Fuel on Nanoparticle Emissions from a Gasoline Passenger Car, Environmental Science \& Technology, 2009.

[32] Mayer A. et al.: Qualitätsstandards und Prüfverfahren für Partikelfilter zur Nachrüstung von Nutzfahrzeugen, MTZ 01/2009.

[33] Mayer A. et al.: Secondary Emissions from Catalytic Active Particle Filter Systems, SAE 2003-01-0291.

[34] Testing of Particle Filter Systems for Internal Combustion Engines, SNR 277205, Source: SNV Schweizerische Normenvereinigung, Winterthur, Schweiz, 2007.

[35] Mayer A. et al.: Retention of Fuel Borne Catalyst Particles by Diesel Particle Filter Systems, SAE 2003-01-0287.

[36] Ulrich A., Wichser A.: Metal analysis of Diesel vehicle emissions, 6th ETH Conference on Nanoparticle Measurement, August 2002.

[37] Czerwinski J. et al.: Nanoparticle Emissions of a DI 2-Stroke Scooter with varying Oil- and Fuel Quality, SAE 2005-01-1101.

Prof. Jan Czerwiński, DEng. - Laboratorium for IC-Engines and Exhaust Gas Control, University of Applied Sciences Biel-Bienne, Switzerland.

Prof. dr Jan Czerwiński - Laboratorium Silników Spalinowych i Emisji Spalin, Uniwersytet Nauk Stosowanych w Biel-Bienne, Szwajcaria. e-mail: jan.czerwinski@bfh.ch

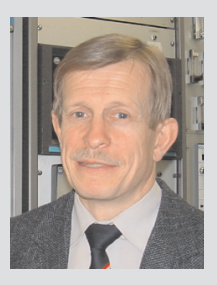

Mr. Andreas Mayer, MEng. - Technik Thermische Maschinen (TTM), Switzerland.

Inż. Andreas Mayer - pracownik Termodynamicznej Techniki Maszyn (TTM), Szwajcaria.

e-mail: ttm.a.mayer@bluewin.ch

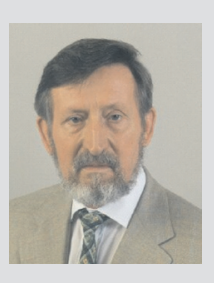

[38] Mooney, Wall flow catalyst for SI engines

[39] Degussa, SAE Wall flow cat. SI engines

[40] SN 181163 Qualitätsrechtlinie für Gerätebenzine in der Schweiz.

[41] Richards R.: DPF technology for older vehicles and high sulphur fuel; SAE 2005-26-020.

[42] Belot G.et al.: Passenger car serial application of a particulate filter system on a common rail direct injection Diesel engine, SAE 2000-01-0473.

[43] Shafer M.M. et al.: Investigation of Platinum and Cerium from use of a FBC; SAE 2006-01-1517.

[44] Richards R. et al.: Results from a $1 / 4$ million $\mathrm{km}$ heavy duty truck using FBC regenerated DPF, SAE 2004-01-0074.

[45] Skillas, Burtscher et al.: Combustion science and Technology, 154, 2000,259-273.

[46] Euro 5/6 für PKW: EC-Regulation No. 715/2007, ec.europa.eu/enterprise/automotive/index_en.htm

[47] Wichmann H.E. et al.: Gesundheitliche Wirkungen von Feinstaub, ecomed 2002. ISBN 3-609-16105-1.

[48] Kattouah P. et al.: Materials for catalyzed and non-catalyzed diesel particulate filters; 5.International CTI-Forum, July 2008 Stuttgart.

[49] Wörle J.M. et al.: Nanoparticle Vanadium oxide potentiated Vanadium toxicity in human lung cells; Environ.Sci.Technol. 2007, 41, 331-336.

[50] Ogami A. et al.: Pathological features of different sizes of nichel oxide following intratracheal instillation in rats; Inhalation toxicology, 19.Feb. 2009.

[51] Karlson H.L. et al.: Copper Oxide nanoparticles are highly toxic: a comparison between metal oxide nanoparticles and carbon nanotubes Chem Res.Toxicol. published on web 08/19/2008.

[52] Riediker M.: A system to test the toxicity of brake wear particles from cars; 12th ETH conference on combustion generated nanoparticles 2008.

Ms. Andrea Ulrich, DEng. - EMPA, Swiss Federal Laboratories for Material Testing and Research, Switzerland.

Dr Andrea Ulrich-EMPA, Szwajcarskie Federalne Laboratorium Inżynierii Materiałowej i Technologii, Szwajcaria.

e-mail:Andrea.Ulrich@empa.ch

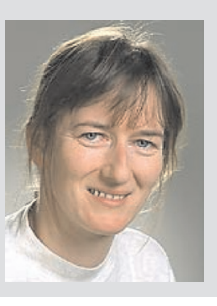

Mr. Adrian Wichser - EMPA, Swiss Federal Laboratories for Material Testing and Research, Switzerland.

Adrian Wichser - EMPA, Szwajcarskie Federalne Laboratorium Inżynierii Materiałowej i Technologii , Szwajcaria.

e-mail:Adrian.Wichser@empa.ch

Mr. Markus Kasper, DEng. - Managing Director of Matter-Aerosol, Switzerland.

Dr Markus Kasper - Dyrektor Zarządzający

w firmie Matter-Aerosol, Szwajcaria.

e-mail: mkasper@matter-engineering.com 